\title{
Saltmarsh archives of vegetation and land use change from Big River Marsh, SW Newfoundland, Canada
}

\author{
Katherine A. Selby ${ }^{1} \cdot$ Helen M. Roe ${ }^{2} \cdot$ Alexander J. Wright $^{1} \cdot$ Orson van de Plassche ${ }^{2} \cdot$ Sally R. Derrett ${ }^{1} \mathbb{D}$
}

Received: 13 December 2020 / Accepted: 27 May 2021 / Published online: 21 June 2021

(c) The Author(s) 2021

\begin{abstract}
Pollen and plant macrofossils are often well-preserved in coastal sediments, providing a palaeoenvironmental record of sea-level and landscape change. In this study, we examine the pollen and plant macrofossil assemblages of a well-dated saltmarsh sediment core from southwest Newfoundland, Canada, to establish recent coastal vegetation and land use change, to increase the knowledge of anthropogenic activities in the area and develop pollen chronozones for reconstructing marsh accumulation rates and to examine the representation of plant macrofossil remains in the wetland pollen profile. Grouping the pollen record into upland and wetland assemblages allows local events related to hydrological change to be separated from landscape-scale changes. The wetland pollen and plant macrofossil records indicate a general acceleration in sea-level rise ca. AD 1700. The sedge pollen and plant macrofossil records attest to multiple phases of rhizome encroachment during inferred periods of marine regression. Two chronozones are identified from the upland pollen profile; the first associated with the settlement of St. George's Bay ca. AD 1800, signalled by increases in Plantago lanceolata and Ambrosia pollen; the second with the permanent settlement of the Port au Port peninsula ca. AD 1850, indicated by increased P. lanceolata and Rumex pollen. Comparison of the plant macrofossil and wetland pollen profiles highlights the underrepresentation of grass pollen preserved in the saltmarsh sediments and a need for further analysis of the zonation, pollen dispersal and macrofossil representation of sedge species in saltmarshes.
\end{abstract}

Keywords Saltmarshes $\cdot$ Pollen stratigraphy $\cdot$ Plant macrofossils $\cdot$ Age-depth model $\cdot$ Chronozones

\section{Introduction}

\section{Saltmarshes as archives of land-use change}

Saltmarshes are highly dynamic environments that possess an intrinsic vertical and horizontal relationship with sea level, producing near-continuous records of sediment accumulation over time (Barlow et al. 2013; Brain et al. 2015; Wright et al. 2017). As such, they are commonly used for

Communicated by K. Brown.

Orson van de Plassche: Deceased

Sally R. Derrett

srderrett1@sheffield.ac.uk

1 Department of Environment and Geography, University of York, 290 Wentworth Way, Heslington YO10 5NG, York, UK

2 School of Natural and Built Environment, Queen's University, Stranmillis Road, Belfast BT9 5AG, UK reconstructions of past sea-level change (Long et al. 2014; Kemp et al. 2015; Barnett et al. 2016). Saltmarshes accumulate sediment and plant remains to maintain their position in the tidal frame in response to relative sea-level (RSL) rise (Kemp et al. 2018). Analysis of microfossil assemblages within saltmarsh sediments, such as Foraminifera, diatoms and testate amoebae, can be used to estimate marsh surface height above mean sea level (Gehrels et al. 2001; Strachan et al. 2015; Wright et al. 2017). Radiocarbon dating of associated plant macrofossil remains provides age control for RSL reconstruction, whilst the age of horizons that are not dated directly can be inferred by interpolation (Kemp et al. 2011, 2018; Wright et al. 2017). The accuracy of the reconstructions produced is determined by the variance of the saltmarsh stratigraphy and lithology, the frequency of horizon dating and the accuracy of the age-depth model employed (Barlow et al. 2013; Wright et al. 2017). Relative sea-level reconstructions based on foraminiferal analyses from saltmarsh sediment cores undertaken by Wright et al. (2011) and Kemp et al. (2017) demonstrate the potential decimetre-scale 
precision of this method when compared with modern tidegauge datasets.

Studies employing age-depth modelling of saltmarsh sediments in the northwest Atlantic region acknowledge the necessity of additional dating proxies (beyond radiocarbon dating) to precisely date recent (the last $\sim 300$ years) and historic short-lived fluctuations in saltmarsh accumulation rates due to plateaus in the calibration curve (Barnett et al. 2017; Shaw et al. 2017; Kemp et al. 2018). Tide gauge records are usually insufficient for use in age-depth modelling as the datasets are often incomplete and document a comparatively short period of time (Batterson and Liverman 2010; Barlow et al. 2013). An evaluation of age-depth model reconstructions based on a well-dated (AMS radiocarbon) saltmarsh sediment core from Pattagansett River Marsh, Connecticut demonstrated the importance of historically dated pollen markers as a complementary dating proxy (Wright et al. 2017).

Landscape change resulting from European settlement is often well-represented in pollen records from eastern North America (e.g. Ireland et al. 2014; Kujawa et al. 2016). For example, Brugam (1978) associated the first appearances of Ambrosia (common ragweed) and Rumex (dock) pollen with the arrival of European farmers in Connecticut around AD 1700. Blarquez et al. (2018) associated an abrupt decline in Fagus (beech) pollen and enhanced microcharcoal levels with human forest clearance in southern Québec from $\mathrm{AD}$ 1800. Brugam (1978) and Anderson (1974) also identified horizons where Castanea (chestnut) pollen declines could be associated with the chestnut blight which originated in
New York from AD 1904. These studies highlight the potential of pollen markers for correlating saltmarsh palaeorecords between sites, reconstructing marsh accumulation rates, as well as providing independent cross-validation of AMS radiocarbon and ${ }^{210} \mathrm{~Pb}$ derived datasets. Roe and van de Plassche (2005) demonstrated that patterns also exist in the local pollen assemblages of modern saltmarsh vegetation zones, which can be related to established tidal datums. Saltmarsh pollen assemblages were thus shown to have significant potential in studies of sea-level change. More recent studies by Kemp et al. (2009, 2011, 2014) have applied pollen chronohorizons as a complementary dating approach in saltmarsh age-depth modelling. In this paper, we examine whether pollen stratigraphic markers can be established for a well-dated saltmarsh in Newfoundland, Canada (Fig. 1). Pollen analysis of saltmarshes in the region is minimal, with the only known palynological investigation undertaken by Brookes et al. (1985) at Hynes Brook Marsh. There is therefore a need for additional chronological information to increase knowledge of the anthropogenic activities in the area and to aid the precision of RSL inferences. This research will enhance the understanding of the late Holocene vegetation history of Big River Marsh and the surrounding upland area. The three major objectives of the research were: (1) To investigate recent coastal vegetation and land use change of the study site through detailed stratigraphic pollen and plant macrofossil analyses of the saltmarsh sediments; (2) to compare the record of vegetation change to local and regional historic events to develop pollen chronozones; (3)
Fig. 1 Location of the study site in Newfoundland, Canada. The location of the Port au Port Peninsula (A), the location of the Big River Marsh study site and the nearby site of Hynes Brook Marsh on the Port au Port Peninsula (B) and the basic geomorphology and sample core location of Big River Marsh are shown $(\mathbf{C})$
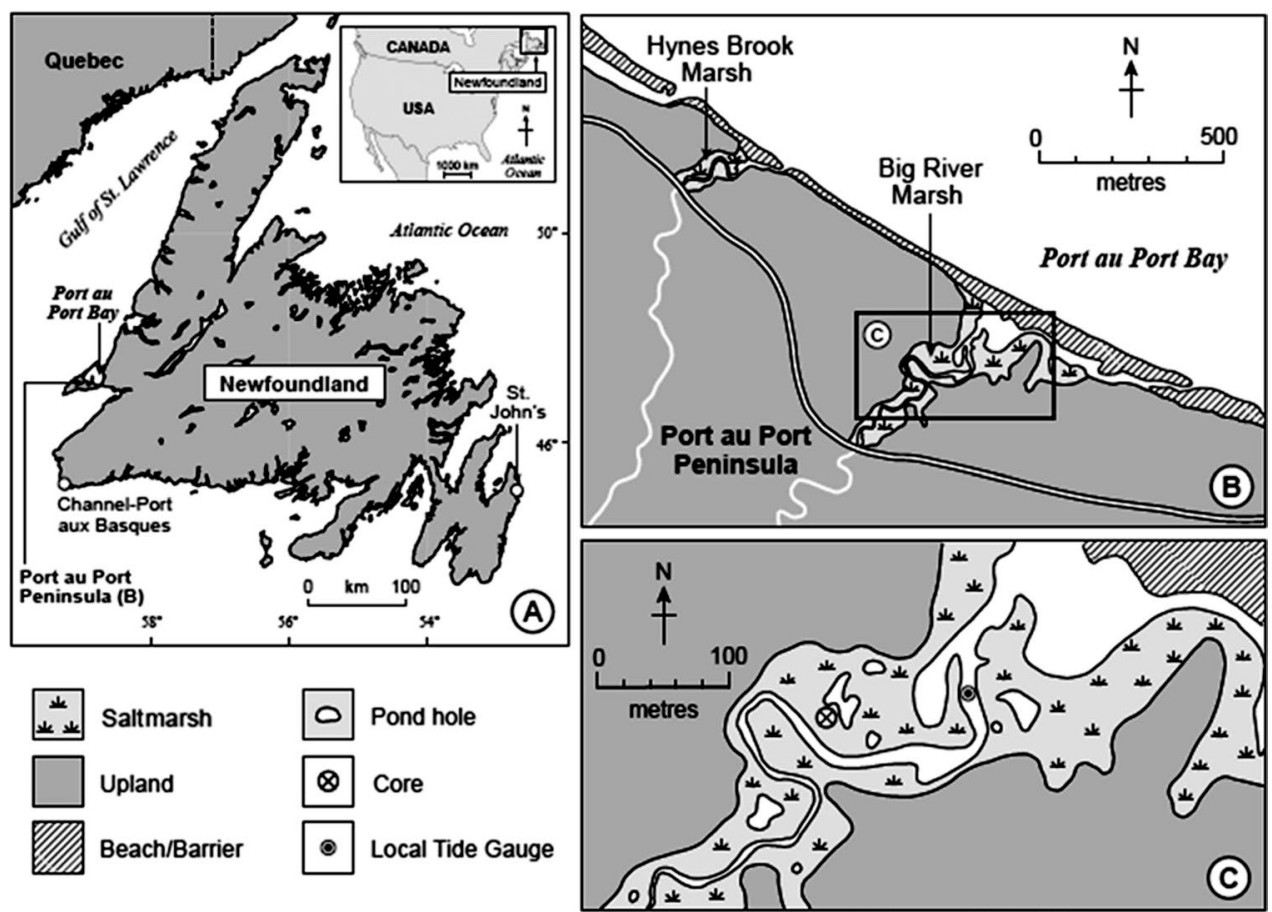
to examine the representation of plant macrofossil remains in the wetland pollen profile.

\section{Study area}

Studies undertaken by Kemp et al. $(2017,2018)$ and Wright et al. $(2011,2017)$ demonstrate that saltmarsh sediments in Newfoundland have yielded well-preserved microfossils and plant remains, revealing an archive of foraminiferal assemblages extending through the mid to late Holocene which have been used to produce age-depth models for RSL reconstruction. Mid to late Holocene RSL records from the saltmarshes of Newfoundland demonstrate the variability of local RSL reconstructions within a single region, with areas in the south and southwest of the province showing a RSL rise and areas in the northwest showing static/falling sea levels (Liverman 1994; Bell et al. 2005; Daly et al. 2007; Billy et al. 2015; Kemp et al. 2018). Variable rates of RSL are mainly attributed to the proximity of Newfoundland to the margin of the former Laurentide ice sheet and the position of the hinge line between areas experiencing RSL rise and RSL fall caused by ongoing glacio-isostatic adjustment (GIA). Newfoundland is therefore an important location for investigating regional, non-linear drivers of RSL (Daly et al. 2007; Kemp et al. 2018). Crustal subsidence due to ocean loading of the Scotian shelf and 20th century eustatic sea level changes caused by global warming have also caused differential changes in RSL in the region (Gehrels et al. 2004). As global sea-levels continue to rise and storm events increase in severity, many lowland areas could be severely impacted, leading to increased coastal flooding and erosion (IPCC 2019). Although saltmarshes can maintain their position in the tidal frame in response to steady rates of RSL rise (Kemp et al. 2018), saltmarsh accumulation may not be able to keep pace with accelerated rates of RSL rise in the future. Understanding trends in late Holocene RSL in Newfoundland is therefore imperative for mitigating against the potential impacts of accelerated RSL rise.

Big River Marsh, southwest Newfoundland, was selected as the study site based on previous studies of the saltmarsh and the neighbouring site of Hynes Brook Marsh (Fig. 1) (Daly et al. 2007; Wright et al. 2011; Kemp et al. 2017, 2018), which demonstrated that the sediments yield nearcontinuous records of RSL extending for at least the last 3,000 years. From analysis of preserved assemblages of Foraminifera and age-depth modelling constrained by AMS radiocarbon dates and elemental abundance lead-isotope analysis, Kemp et al. (2018) concluded that RSL had risen by $\sim 3 \mathrm{~m}$ at the site over the last 3,000 years, with 20th century RSL occurring at the fastest century-scale rate of the study period.

Big River Marsh has developed in the shelter of a barrier beach at the mouth of Big River, on the southern coast of
West Bay (Fig. 1), one of two basins formed between Long Point, the Port au Port isthmus and the west coast of Newfoundland (Brookes et al. 1985). The saltmarsh is underlain by approximately $3 \mathrm{~m}$ of saltmarsh peat and is presently fed by small streams (Wright and van de Plassche 2001). The diurnal tidal range (mean lower low water to mean higher high water) is $1.06 \mathrm{~m}$ (Kemp et al. 2018). Monthly average air temperatures reach $\sim 16^{\circ} \mathrm{C}$ in summer and are below freezing from December to March (Canadian Climate Normals for 1971-2000, Stephenville A $48^{\circ} 32^{\prime} \mathrm{N}, 58^{\circ} 33^{\prime} \mathrm{W}$ ).

Bertness (1991) describes the zonation of saltmarsh plants in the region as being comprised of a low marsh habitat which is covered daily by tides (low marsh), a high marsh habitat which borders the sea (high marsh), and a high marsh habitat which borders the hinterland (upper marsh). A clear vegetation zonation is evident on the saltmarsh. The low marsh zone is dominated by Spartina alterniflora (smooth cordgrass), which is characteristic of most Newfoundland low marsh zones (Thannheiser 1981), and Salicornia (glasswort) spp. The high marsh zone is characterised by Spartina patens (saltmeadow cordgrass), Distichilis spicata (seashore saltgrass), Plantago maritima (sea plantain) and Triglochin maritima (saltmarsh arrow-grass), and the upper marsh by Iva апnиа (marsh elder), Cyperaceae (sedge) and some Juncus (rushes) spp. At the landward limit of the marsh, vegetation is dominated by Cyperaceae and Poaceae (grasses) alongside Abies balsamea (balsam fir), Pinus (pine) spp., Betula (birch) spp., Iris versicolor (blue flag) and Iva anпиa. The regional vegetation is mainly coniferous forest, of which A. balsamea is the dominant tree species, alongside lesser amounts of Picea glauca (white spruce), P. mariana (black spruce) and Pinus strobus (white pine) (Levac 2003).

Limited Holocene pollen records from western Newfoundland (Brookes et al. 1985; Brown Macpherson 1995; Levac 2003; Levac et al. 2018) show that vegetation change correlated with fluctuations in the Atlantic Meridional Overturning Circulation, which plays a vital role in regulating climate in the North Atlantic region (Blundell et al. 2018). The Holocene vegetation record commenced with Betula and Alnus (alder) shrubland from 11 to $9.5 \mathrm{kyr}$ вP, followed by an expansion in Picea, signalling spruce forest establishment (Levac 2003). Between 9.5 and $6.5 \mathrm{kyr}$ BP, boreal forest became established in the area, with Picea and Pinus coniferous forest and Betula shrubland (Brown Macpherson 1995; Levac 2003). Evidence of a delay in Pinus forest establishment in coastal areas of southwestern Newfoundland suggests that ocean temperatures remained low in this period (Brown Macpherson 1995). From 6.5 to 4 kyr BP, tree pollen abundance increased with greater amounts of Pinus and deciduous species; signifying warmer summers and a longer growing season than at present (Brown Macpherson 1995; Levac 2003). Pollen records from the last 4,000 years indicate a cooler, wetter climate with a decline in Pinus 
species and an increase in Picea forest with areas of shrubland (Brown Macpherson 1995; Levac 2003). European settlement of western Newfoundland is indicated in pollen records by increases in Ambrosia and graminoid taxa from around 400 years BP (Levac 2003; Levac et al. 2018). In the Port au Port peninsula, anthropogenically induced vegetation changes are likely evident at the end of the 1700s when Acadian settlers developed an economy in the area based on farming and fishing (Butt 2017). Mannion (1977) notes that populations increased from 20 families to 1600 people by the end of the $1800 \mathrm{~s}$, as the area became a productive lobster fishing site, and railway construction brought new businesses and services. A second wave of settlement is discussed by Butt (2017) in the early 1900s, as French settlers occupied the westernmost extremities of the peninsula. Earlier small-scale vegetation changes may be evident when marine-orientated ancestors of the Beothuk people (Cow Head, Beaches and Little Passage complexes) inhabited the island from ca. 2,000 to 400 years BP (Westley et al. 2011). Archaeological sites dated to the period are evident across the Port au Port Peninsula (Tourism, Culture, Arts and Recreation, ND) and a large chert outcrop identified by Simpson (1986) at West Bay may have drawn prehistoric populations to the area. There is the possibility that Norse settlers who briefly inhabited northern Newfoundland at ca. AD 1000 may have frequented other coastal areas of the island (Westley et al. 2011).

\section{Methodology}

\section{Field methods}

Stratigraphic investigations were undertaken in the field using a hand-held Dutch peat auger and the sediments logged according to the Troels-Smith (1955) classification system. A representative sample core was collected for micropalaeontological and sedimentary analyses from an undisturbed marsh location away from the Big River Marsh tidal channel (Fig. 1). The core (hereafter referred to as core BRM1) was extracted with overlapping segments using a Russian corer. The core sections were placed in plastic guttering and sealed with plastic film, before transit to the Netherlands. Here they were stored under refrigerated conditions (ca. $4{ }^{\circ} \mathrm{C}$ ) prior to analysis. To establish marsh surface elevations, a temporary benchmark (wooden post) was buried in the marsh sub-surface, and core BRM1 and reconnaissance boreholes were surveyed into this point. The surface elevation of the BRM1 core was established at $0.11 \mathrm{~m}$ above NAD83 (North American Datum 1983).

\section{Laboratory methods}

The upper metre of the BRM1 core was used to investigate the potential for developing pollen-delimited chronostratigraphic horizons associated with human settlement and regional vegetation change, and to examine the significance of the wetland pollen and plant macrofossil remains.

Radiocarbon dating and age-depth model: The radiocarbon dates (Table 1) and age-depth model were derived from a previous study of Big River Marsh, in which core BRM1 was subsampled for Foraminifera and testate amoebae analysis (see Kemp et al. (2018) for full methodology). Fourteen AMS radiocarbon dated samples of plant macrofossil remains (palaeomarsh-surface indicators) provide a detailed chronology for the upper $(104 \mathrm{~cm})$ sediments of BRM1 (Table 1). To facilitate comparisons between the historical land use records and the radiocarbon dated core, all ${ }^{14} \mathrm{C}$ dates were calibrated to calendar years $(2 \sigma)$ using the probability method in CALIB version 6.0.2 (Stuiver and Reimer 1993; Stuiver et al. 2005) and the IntCal09 atmospheric dataset (Reimer et al. 2009). The original 'field' depth of core Sect. 2 has been subject to vertical adjustment, following cross correlation of pollen and loss-on-ignition data with core 1 , by $6 \mathrm{~cm}$ following (bio-) stratigraphic correlation.

The age-depth model was constructed using the Clam code (Blaauw 2010) written in $\mathrm{R}$ ( $\mathrm{R}$ Development Core Team 2010). One thousand iterations of LOWESS smoothing (initially spanning 0.75 ) were used to interpolate between dated horizons ('best' single age by weighted mean $\pm 95 \%$ confidence interval). A LOWESS span of 1.0 was favoured as a more rigid smoothing was considered appropriate for the short length of the series. The modern analogue technique (MAT) was applied to gauge similarity between assemblages of modern and fossil Foraminifera (e.g. Gehrels 2000; Hayward et al. 2004). Weighted averaging-based transfer function methods extracted the elevation of species optima and tolerance within the local tidal frame and these were applied to reconstruct the height at which fossil Foraminifera assemblages formed relative to palaeotide levels.

Pollen and other palynomorphs: Saltmarsh sediments were sampled at $2 \mathrm{~cm}$ increments throughout the sediment core. Pollen preparation followed standard procedures (Barber 1976). Samples (1-3 $\left.\mathrm{cm}^{3}\right)$ were boiled with $20-25 \mathrm{ml}$ $10 \%$ potassium hydroxide $(\mathrm{KOH})$ and then sieved through a 200-250 micron mesh. The samples were centrifuged for $1 \mathrm{~min}$ at 2,000 rpm, before acetolysis and heavy liquid separation procedures were undertaken. The samples were stored in glycerol.

Pollen was counted using a light microscope under 400x magnification. To ensure that pollen derived from both the wider landscape (upland) and from the saltmarsh itself (wetland) was well represented, at least 500 pollen grains were 
Table 1 Radiocarbon dates for core sections 1 and 2 (after Kemp et al. 2018)

\begin{tabular}{|c|c|c|c|c|c|c|c|c|c|}
\hline $\mathrm{UtC}$ & No & Depth $(\mathrm{cm})$ & Core section & Datedmat & PMS $(\mathrm{cm})$ & $\delta^{13} \mathrm{C}(\% 0)$ & ${ }^{14} \mathrm{C}$ age $\pm 1 \sigma$ & Median (AD) & $2 \sigma$ ranges $(\mathrm{AD})$ \\
\hline 10,371 & 1 & $9-11$ & 1 & $S p$ & $5 \pm 4$ & -13.8 & $-14 \pm 31$ & - & Modern (post 1950's) \\
\hline 10,372 & 2 & $17-19$ & 1 & $S p$ & $13 \pm 4$ & -12.3 & $76 \pm 29$ & 1850 & $\begin{array}{l}1691-1729 \\
1810-1922 \\
1952-1954\end{array}$ \\
\hline 10,373 & 3 & $25-27$ & 1 & $S p$ & $21 \pm 4$ & -12.3 & $143 \pm 41$ & 1807 & $\begin{array}{l}1667-1782 \\
1797-1893 \\
1906-1953\end{array}$ \\
\hline 10,374 & 4 & $33-35$ & 1 & $S p$ & $29 \pm 4$ & -12.8 & $176 \pm 31$ & 1772 & $\begin{array}{l}1655-1696 \\
1725-1814 \\
1835-1877 \\
1917-1952\end{array}$ \\
\hline 10,375 & 5 & $41-43$ & 1 & $\mathrm{Cr}$ & $41 \pm 1$ & -26 & $125 \pm 39$ & 1824 & $\begin{array}{l}1673-1778 \\
1799-1898 \\
1901-1942 \\
1950-1953\end{array}$ \\
\hline 10,376 & 6 & $49-51$ & 1 & $\mathrm{Cr}$ & $49 \pm 1$ & -26.4 & $125 \pm 35$ & 1826 & $\begin{array}{l}1675-1777 \\
1799-1897 \\
1902-1941 \\
1950-1953\end{array}$ \\
\hline 10,517 & 10 & $55-57$ & 1 & $S p$ & $51 \pm 4$ & -13.2 & $233 \pm 26$ & 1667 & $\begin{array}{l}1638-1681 \\
1739-1744 \\
1763-1802 \\
1938-1951\end{array}$ \\
\hline 10,516 & 9 & $61-63$ & 1 & $\mathrm{Cr}$ & $61 \pm 1$ & -26.5 & $286 \pm 33$ & 1571 & $\begin{array}{l}1491-1602 \\
1614-1665 \\
1786-1792\end{array}$ \\
\hline 10,515 & 8 & $67-69$ & 1 & $\mathrm{Cr}$ & $67 \pm 1$ & -26.8 & $332 \pm 34$ & 1560 & $1471-1643$ \\
\hline 10,470 & 7 & $75-77$ & 1 & $S p$ & $71 \pm 4$ & -12.7 & $367 \pm 33$ & 1522 & $\begin{array}{l}1448-1529 \\
1543-1634\end{array}$ \\
\hline 10,518 & 11 & $81-83$ & 1 & $S p$ & $77 \pm 4$ & -12.1 & $415 \pm 40$ & 1474 & $\begin{array}{l}1423-1523 \\
1559-1563 \\
1571-1630\end{array}$ \\
\hline 10,519 & 12 & $81-83$ & 2 & $S p$ & $77 \pm 4$ & -13.1 & $530 \pm 34$ & 1409 & $\begin{array}{l}1317-1353 \\
1389-1442\end{array}$ \\
\hline 10,520 & 13 & $89-91$ & 2 & $S r$ & $87.5 \pm 2.5$ & -13.6 & $546 \pm 42$ & 1392 & $\begin{array}{l}1304-1365 \\
1384-1440\end{array}$ \\
\hline 10,521 & 14 & $102-104$ & 2 & $\mathrm{Tm}$ & $102 \pm 1$ & -28.1 & $846 \pm 38$ & 1195 & $\begin{array}{l}1048-1086 \\
1123-1138 \\
1150-1267\end{array}$ \\
\hline
\end{tabular}

Dated plant macrofossils include: (Sp) Spartina patens; (Cr) Carex rostrata; (Tm) Triglochin maritima; (Sr) Scirpus robustus. Abbreviations: $($ Depth $)=$ laboratory adjusted sample depth in core; $(\mathrm{PMS})=$ estimated depth of palaeo-marsh surface; $\left(\delta^{13} \mathrm{C}\right)=$ abundance of ${ }^{13} \mathrm{C}$ relative to ${ }^{12} \mathrm{C}$ with respect to PDB reference; $\left({ }^{14} \mathrm{C}\right.$ age $\left.\pm 1 \sigma\right)={ }^{14} \mathrm{C}$ age in years before present (BP) with associated $1 \sigma$ error and normalised to $\delta^{13} \mathrm{C}=-25 \%$; $($ Median $)=$ median calibrated age in calendar years $(\mathrm{AD}), 2 \sigma$ ranges; calibrated $2 \sigma$ age ranges in calendar years $(\mathrm{AD})$

counted per level. Pollen and spore taxa were identified with reference to the keys of McAndrews et al. (1973), Faegri and Iversen (1989) and Moore et al. (1991). Pollen percentage profiles were constructed using C2 software (Juggins 2007) (Figs. 3, 4). To avoid any potential errors in distinguishing the dispersal of pollen grains from transitional vegetation communities, the pollen was sub-divided into three main source groupings: upland, wetland and indeterminate source (Table 2), following the approach used by Roe and van de Plassche (2005). The upland group includes pollen from taxa which grow in the marginal upland and hinterland of the study area, while the wetland taxa comprise those which are commonly found in intertidal marshes, including Poaceae. The indeterminate group comprises pollen which cannot be defined as being derived from either upland or wetland sources. Grouping the taxa in this way allows both regional (upland) land use change events and fluctuations in local (wetland) saltmarsh conditions to be examined.

The pollen diagrams were zoned using Constrained Incremental Sums of Squares (CONISS) cluster analysis, undertaken in $\mathrm{R}$ version 3.6.1 (R Core Team 2019) using the rioja package (Juggins 2017). Foraminiferal test linings and 
Table 2 Pollen taxa source area groups (following Roe and van de Plassche 2005)

\begin{tabular}{lll}
\hline Upland & Indeterminate Source & Wetland \\
\hline Pinus & Artemisia & Poaceae \\
Betula & Caryophyllaceae & Cyperaceae \\
Picea & Asteraceae & Potamogeton \\
Abies & Brassicaceae & Armeria maritima \\
Carya & Equisetum & Chenopodiaceae \\
Quercus & Ericales & Caryophyllaceae \\
Acer & Filipendula & Elodea \\
Alnus & Menyanthes trifoliata & Lycopodium lucidulum \\
Ulmus & Lamiaceae & Lycopodium \\
Castanea & Cichorieae & Typha latifolia \\
Fraxinus & Lilium martagon & Typha angustifolia \\
Ostrya & Polygonum & Polypodium \\
Carpinus & Ranunculaceae & Selaginella selagi- \\
& & noides \\
Corylus & Rosaceae & \\
Ilex & Sanguisorba & \\
Salix & Apiaceae & \\
Ambrosia & Filicales & \\
Plantago lanceolata & Sphagnum & \\
Plantago & & \\
Rumex & & \\
\hline & &
\end{tabular}

other non-pollen palynomorphs (e.g. fungal spores) were also enumerated, when present, and are included in the wetland pollen diagram (Fig. 4). Microscopic charcoal identified on the pollen slides was counted following the method outlined by Clark (1982) and included in the upland pollen diagram (Fig. 3).

Plant macrofossils: These were analysed at $1 \mathrm{~cm}$ intervals contiguously throughout the BRM1 core following the methods outlined by Mauquoy et al. (2010), whereby subsamples $\left(5 \mathrm{~cm}^{3}\right)$ were treated with $5 \% \mathrm{KOH}$ and heated for $45 \mathrm{~min}$, then disaggregated in cold water and washed through a $100 \mu \mathrm{m}$ sieve. The macroscopic plant remains, typically comprising rootlets, rhizomes and sub-surface stems of intertidal grass and sedge species, were picked from the residues using a low power microscope and identified through comparison with modern reference data. The vascular plant remains identified are expressed in percentage values of the total volume of sieved sediment. Plant macrofossil percentage profiles were plotted using C2 software (Juggins 2007) (Fig. 5) and the plant macrofossil diagram was zoned using CONISS cluster analysis, undertaken in $\mathrm{R}$ version 3.6.1 ( $\mathrm{R}$ Core Team 2019) using the rioja package (Juggins 2017).

Loss-on-ignition: The non-volatile organic matter content of the sample core was determined using the loss-on-ignition method outlined by Heiri et al. (2001). Sampling was carried out at $2 \mathrm{~cm}$ increments throughout the core. The samples were weighed in crucibles before being dried in an oven at $105{ }^{\circ} \mathrm{C}$ for $12 \mathrm{~h}$ and the dry weight recorded. The samples were then placed in a muffle furnace at $550^{\circ} \mathrm{C}$ for $3 \mathrm{~h}$ before recording the final post-ignition weight (samples were left to cool in a desiccator between each stage). Organic matter content was calculated using the formula:

LOI550 $=(($ DW105 - DW550 $) /$ DW105 $)) * 100$

where LOI550 represents the post combustion weight of the sample as a percentage, DW105 represents the dry precombustion weight of the sample and DW550 represents the post combustion weight.

\section{Results}

\section{Stratigraphy, radiocarbon dating and age-depth model}

The stratigraphy at Big River Marsh consists of a substrate of glacially derived consolidated, grey-blue silt and clay, overlain by saltmarsh peat with abundant plant remains (Kemp et al. 2018). The BRM1 core was composed entirely of high and upper marsh peat (Fig. 2). A total of 14 radiocarbon dates obtained on plant macrofossils in the sample core (Kemp et al. 2018; Table 1) reveal that the upper metre of sediment accumulated during the past $\sim 951$ years. The $2 \sigma$ ranges are wide, particularly in the upper $63 \mathrm{~cm}$, and there is an overlap in the median calibrated age of samples taken between 57 and $25 \mathrm{~cm}$, which could be a consequence of pre-treatment sample contamination (Wohlfarth et al. 1998).

The average organic content of the saltmarsh sediments (LOI; 37.6\% \pm 9.3 ; Fig. 2) generally increases through the BRM1 core (from base to top). The organic content is significantly below the mean at $63 \mathrm{~cm}(6.3 \%)$ and significantly above the mean at $47 \mathrm{~cm}(64.9 \%)$. The age-depth model indicates an accumulation rate of $1.35 \mathrm{~mm} \mathrm{a}^{-1}$ in the upper metre of the core, with an apparent acceleration in palaeomarsh surface accumulation at ca. AD 1700, coincident with an increase in organic carbon (Fig. 2).

\section{Pollen and plant macrofossils}

The pollen and plant macrofossil diagrams have been divided into zones which represent the major changes of vegetation at the site. The pollen zone descriptions for upland pollen (Fig. 3), wetland pollen (Fig. 4) and plant macrofossils (Fig. 5) are shown in Table 3. 
Fig. 2 a Graph to show the stratigraphy and Loss-on-Ignition (LOI) (\%) data with increasing core depth $(\mathrm{cm})$ and median ${ }^{14} \mathrm{C}$ ages from Kemp et al. (2018). b The age-depth model for Big River Marsh core BRM1 (after Kemp et al. 2018)

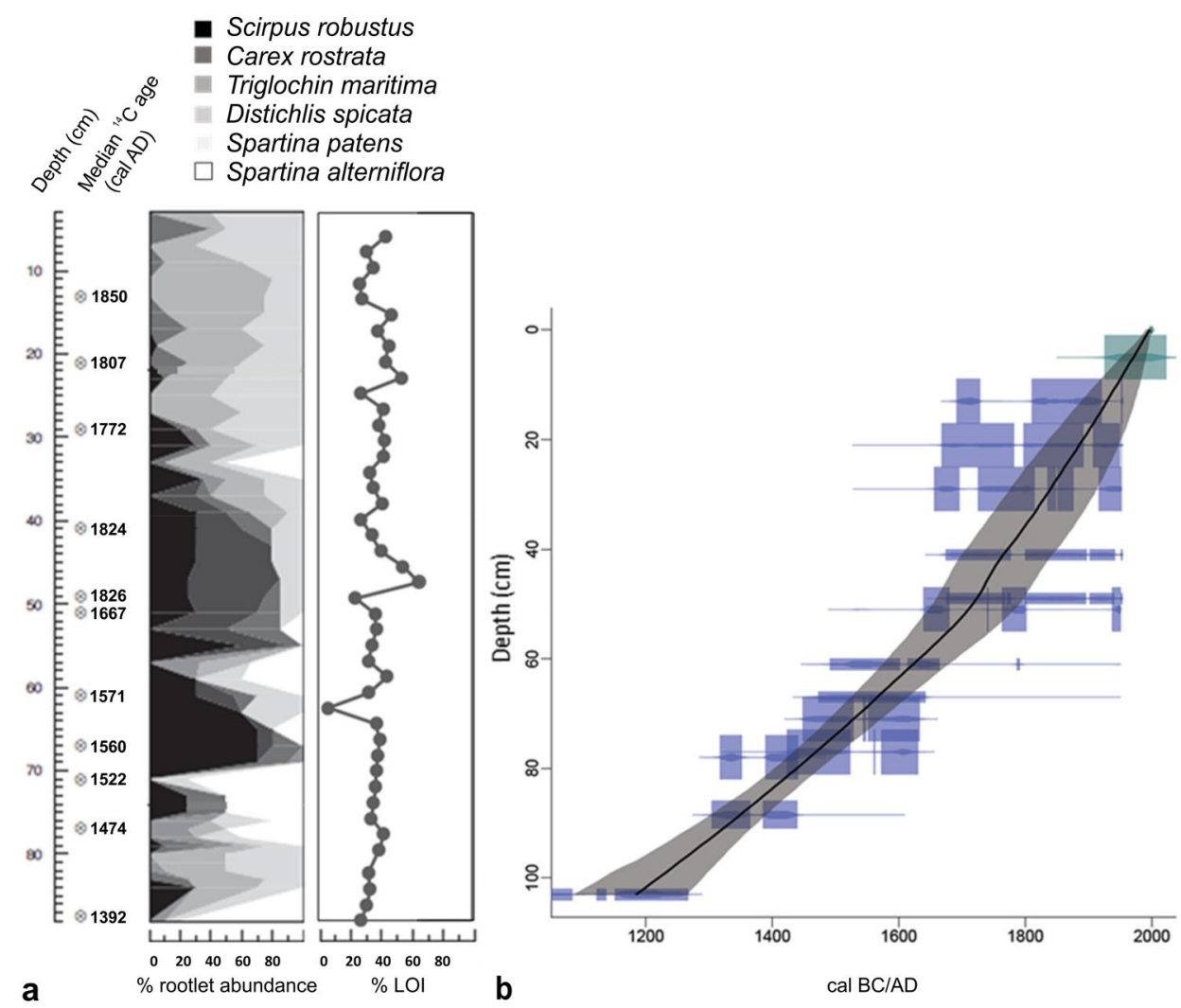

\section{Pollen and plant macrofossil representation}

The wetland pollen assemblage of the BRM1 core is dominated by Cyperaceae (up to 45\%), Potamogeton (up to 45\%) and Poaceae pollen (up to 18\%), whilst the plant macrofossil assemblage includes the remains of three common saltmarsh grass species of the Poaceae family (Distichlis spicata, Spartina patens and S. alterniflora), two sedge species of the Cyperaceae family (Scirpus robustus and Carex rostrata) and Triglochin martima. A combined plot which shows the Cyperaceae and Poaceae pollen, the plant macrofossil assemblage and the Foraminifera-derived reconstruction of palaeo-marsh elevation (from Kemp et al. 2018) for BRM1 is given in Fig. 6. The plot highlights the broad correspondence in the relative abundance of the pollen and plant macrofossils for taxa in the same family. For example, in pollen zone BRW-2, where Cyperaceae levels peak, Carex rostrata macrofossils also reach peak abundance (up to 60\%). Elsewhere in the core the Scirpus robustus and C. rostrata macrofossil remains and Cyperaceae pollen abundance show a vertical offset, e.g. S. robustus rootlet percentages peak between 67 and $69 \mathrm{~cm}$ (up to 70\%) and C. rostrata at $47 \mathrm{~cm}$, whilst Cyperaceae pollen percentages peak at $31 \mathrm{~cm}$. Similarly, between 3 and $17 \mathrm{~cm}$, where the remains of the two species are absent in the macrofossil record, Cyperceae pollen levels persist at 10-19\%. Although the correspondence between the Poaceae pollen assemblages and the Poaceae plant macrofossil record is less well pronounced, peak levels of Poaceae pollen occur just after peak abundances of $S$. alterniflora macrofossils (70\%). The Foraminifera-derived reconstruction of palaeo-marsh elevation (PME) shows little change throughout the period of deposition (Fig. 6). There nevertheless appears to be a subtle inverse relationship between the relative abundance of Cyperaceae pollen and the inferred PME in parts of the core. For example, where the lowest sedge pollen value of BRM1 (7\%) occurs at $73 \mathrm{~cm}$, the palaeo-marsh elevation is highest at $167 \mathrm{~F}-\mathrm{SWLI}$ (standardised water level index units, where a value of 100 corresponds to mean tide level and 200 is the highest occurrence of Foraminifera), and where the highest Cyperaceae value $(45 \%)$ occurs at $31 \mathrm{~cm}$, the palaeo-marsh elevation is lowest at $148 \mathrm{~F}-\mathrm{SWLI}$.

\section{Interpretations and discussion}

\section{Upland environmental changes}

The upland pollen assemblage from Big River Marsh indicates a continuous presence of Picea and Betula woodland from at least ca. AD 1392 to the present day, comparing well with other studies in the region (Brookes et al. 1985; Brown Macpherson 1995; Levac 2003). Fluctuations in Corylus, Alnus and herb pollen indicate phases of hydrological 


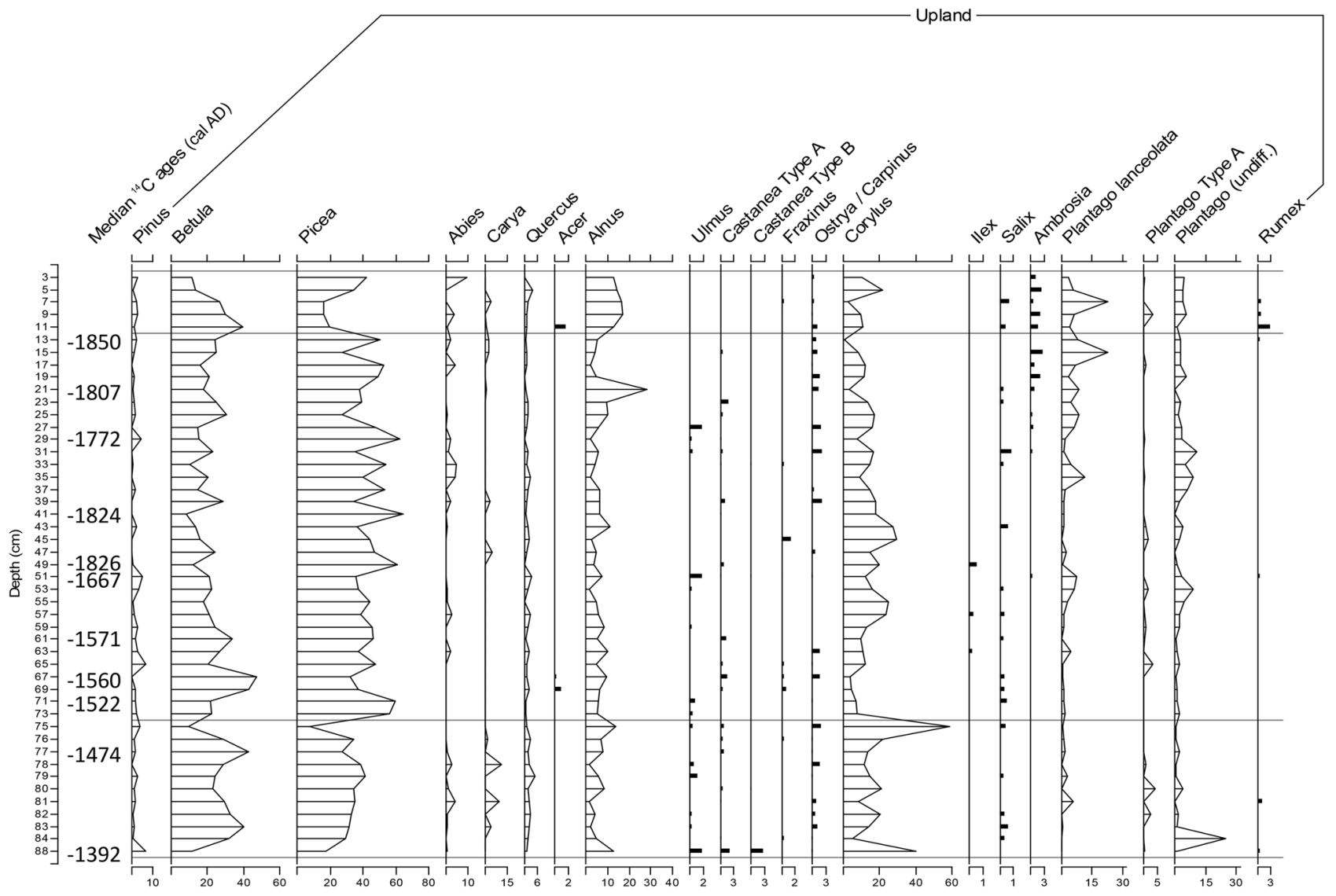

Fig. 3 Percentage upland and indeterminate source pollen and spore frequency diagram from Big River Marsh core BRM1

change and subtle human-induced vegetation changes in the area surrounding the saltmarsh.

Ca. AD 1392-1522: From ca. AD 1392, consistently high pollen concentrations indicate a relatively dense coverage of Betula and Picea forest, with a Corylus and Alnus shrub understorey. High levels of undifferentiated Plantago (plantain) pollen in the lower assemblage may indicate P. maritima expansion in the high marsh. The increase in microcharcoal levels at $80 \mathrm{~cm}$ accompanies a slight reduction in Betula pollen and increased Plantago pollen levels. Disturbance could be attributed to ancestors of the Beothuk, whose presence in the area is indicated by the local assemblage of artefacts of the Little Passage complex (Simpson 1986). The ancestral Beothuk appeared to favour sheltered coastal sites such as Big River Marsh, allowing them to exploit the resources of both the coastline and the surrounding uplands (Pastore 1989; Holly et al. 2015). Similarly, at ca. AD 1500, there are significant decreases in Betula and Picea, corresponding with notable peaks in Corylus and Asteraceae (aster) pollen, and an increase in Alnus, indicating a further disturbance event. Corylus pollen production is often enhanced in disturbed environments (Bégeot 1998) and has been correlated with increased forest fire events in some studies (Finsinger et al. 2006). The ca. AD 1500 disturbance event could be attributed to a local natural or human-induced forest fire, although there is no corresponding peak in microcharcoal levels.

Ca. AD 1522-1850: From ca. AD 1522, an increase in Picea pollen frequencies signifies increased Picea forest coverage with fluctuating levels of Betula, Corylus and Alnus shrubs. At ca. AD 1600 there is also a prolonged period of low microcharcoal levels, indicating reduced forest fire frequency. Reforestation may signal a withdrawal of ancestral Beothuk populations from the area. The event coincides with an overall decline in native populations across the region, instigated by European colonisation (Pastore 1989; Liebmann et al. 2016). From ca. AD 1650 there is a steady increase in P. lanceolata, indicating an increase in disturbed, open and grassy areas (Clapham et al. 1987). The increased disturbance could be attributed to the presence of nomadic human populations in the area. The presence of the Mi'kmaq people is documented in southern Newfoundland from at least the early 1500s (Martijn 2003). Historic accounts suggest that the Mi'kmaq frequented coastal areas at the mouth of big rivers (such as Big River Marsh) in the summer months, allowing access to fishing areas as well as providing 


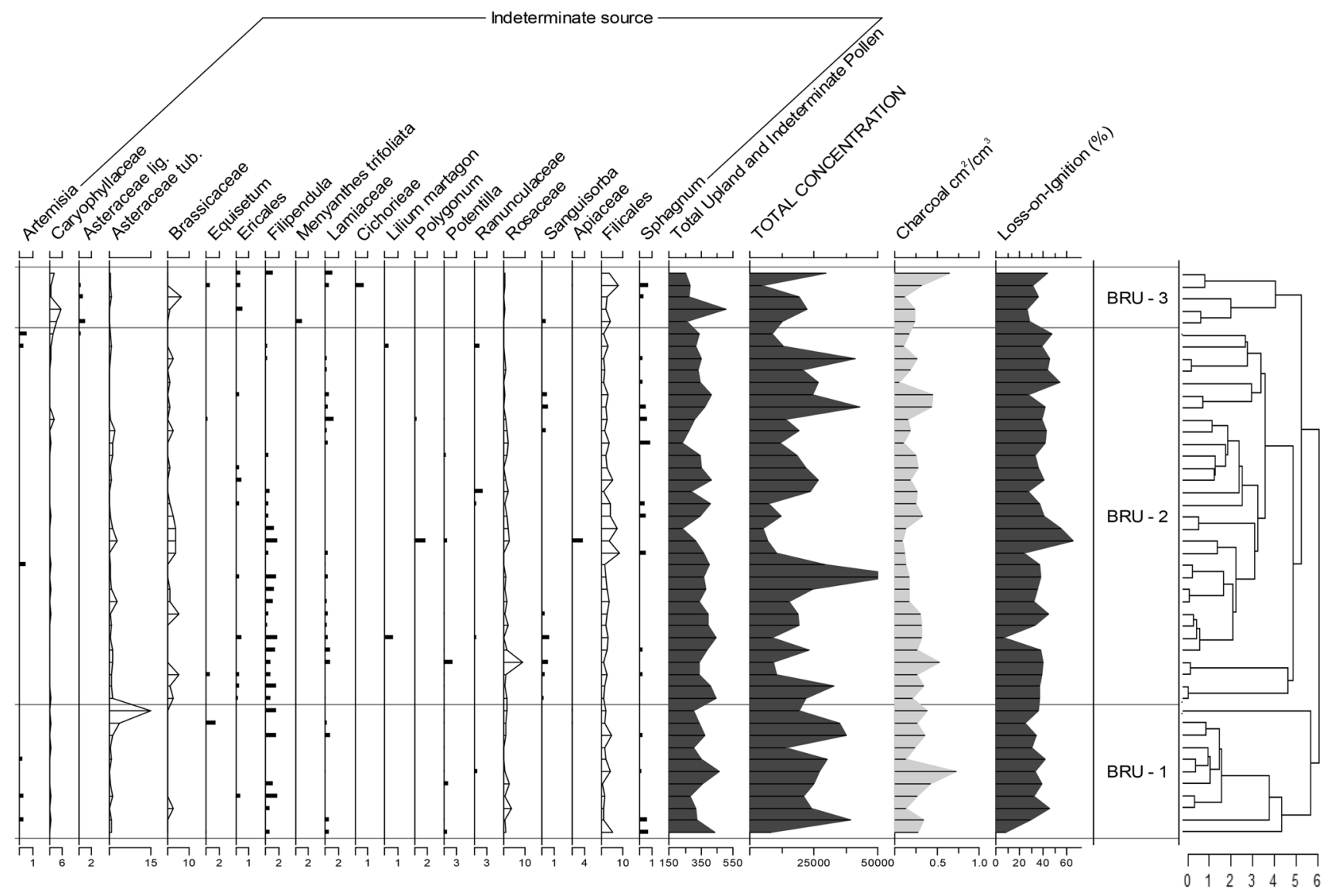

Fig. 3 (continued)

an inland transportation route for goods such as furs and hides for trade with Europeans (Martijn 2003). There is a notable peak in P. maritima at ca. AD 1800 , alongside a small increase in Ambrosia pollen. Brookes et al. (1985) record a concurrent rise in Plantago pollen levels at Hynes Brook Marsh. The rise may coincide with a historic account from AD 1794, detailing the presence of a permanent Mi'kmaq community at St. George's Bay (approximately $10 \mathrm{~km}$ southwest of Big River Marsh) consisting of at least 19 families (Martijn 2003). Mannion (1977) also details the presence of European settlers in the area from the late 1700s, with 13 families of European origin documented in the St George's Bay area in AD 1818.

Post AD 1850: From ca. AD 1850 there is a notable decrease in Picea pollen, alongside a second peak in Plantago lanceolata, an increase in Alnus, Corylus and Rumex pollen and the continued presence of Ambrosia pollen. Ambrosia is frequently associated with European settlement in North American pollen records (Brugam 1978; Tolonen 1983; Fuller et al. 1998). A similar expansion of Ambrosia pollen is also noted in the period at the Bay of Islands (western Newfoundland) (Levac 2003). The increase in ruderal species and shrubs may be associated with land clearance and domestic grazing of the saltmarsh following increased settlement of the Port au Port Peninsula in the later 1800s (Roberts and Robertson 1986; Butt 2017; Levac et al. 2018). Barter (1986) outlines a witness account of the presence of approximately five to six hundred individuals in the $\mathrm{St}$ George's area in 1842, who were thought to occupy the area seasonally for fishing. The decrease in Picea pollen in this period could also be associated with deliberate timber felling in the region as fishermen were able to supplement their income by cutting wood for the sawmill established at Corner Brook in 1865 (Mannion 1977). Fishermen may have become more reliant on the timber industry towards the end of the century, as cod fishing stocks are thought to have become severely depleted on the west coast by 1875 (Barter 1986).

The increase in charcoal concentrations observed at the top of the pollen profile is potentially associated with increased human activity. Documentary evidence of anthropogenically derived forest fires is common around inhabited areas in the period of European settlement in Newfoundland (Jessen et al. 2011). However, microcharcoal fragments observed on pollen slides usually derive from a wide catchment and can be subject to increased breakage when 


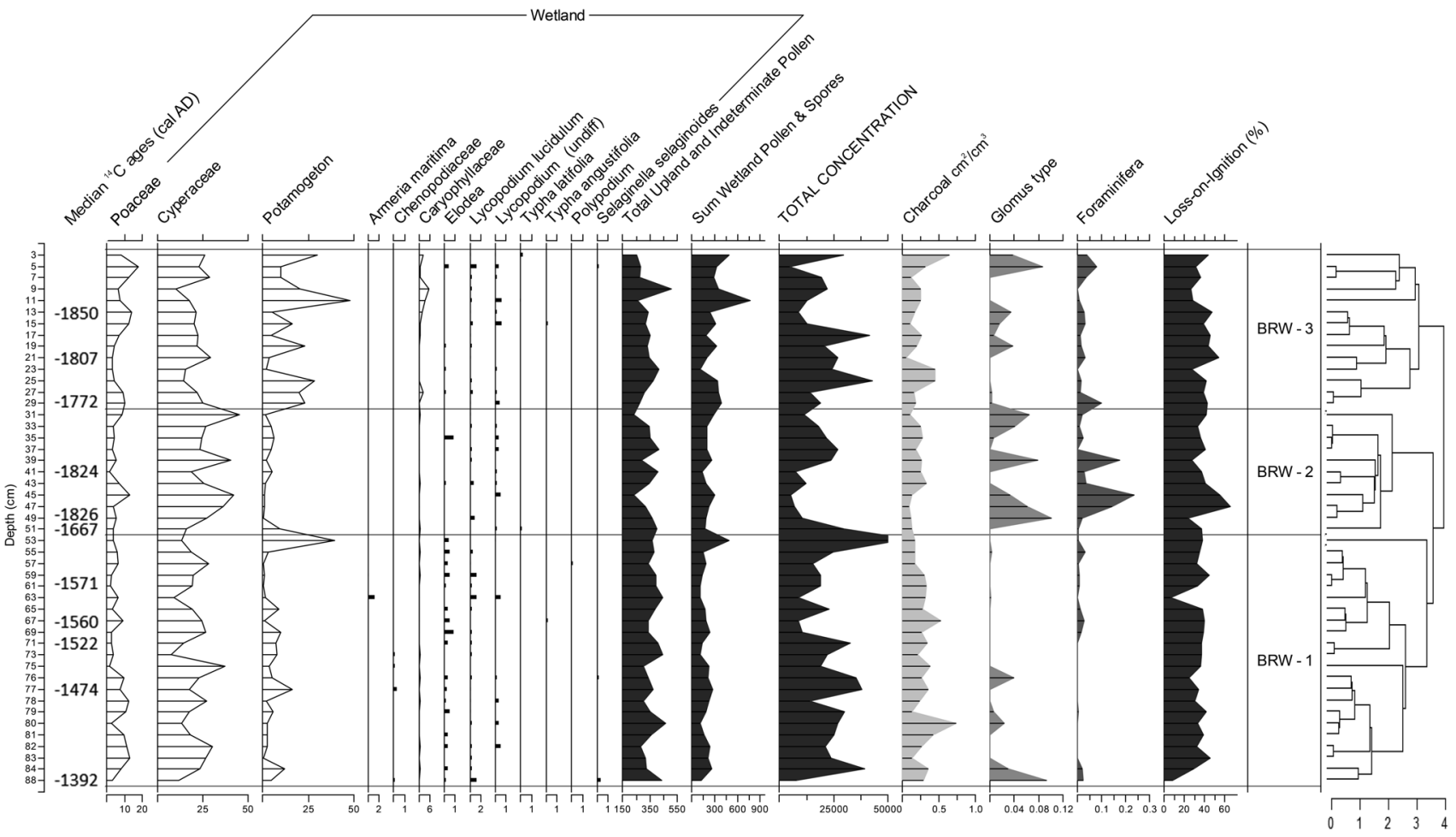

Fig. 4 Percentage wetland pollen and spore frequency diagram for Big River Marsh core BRM1

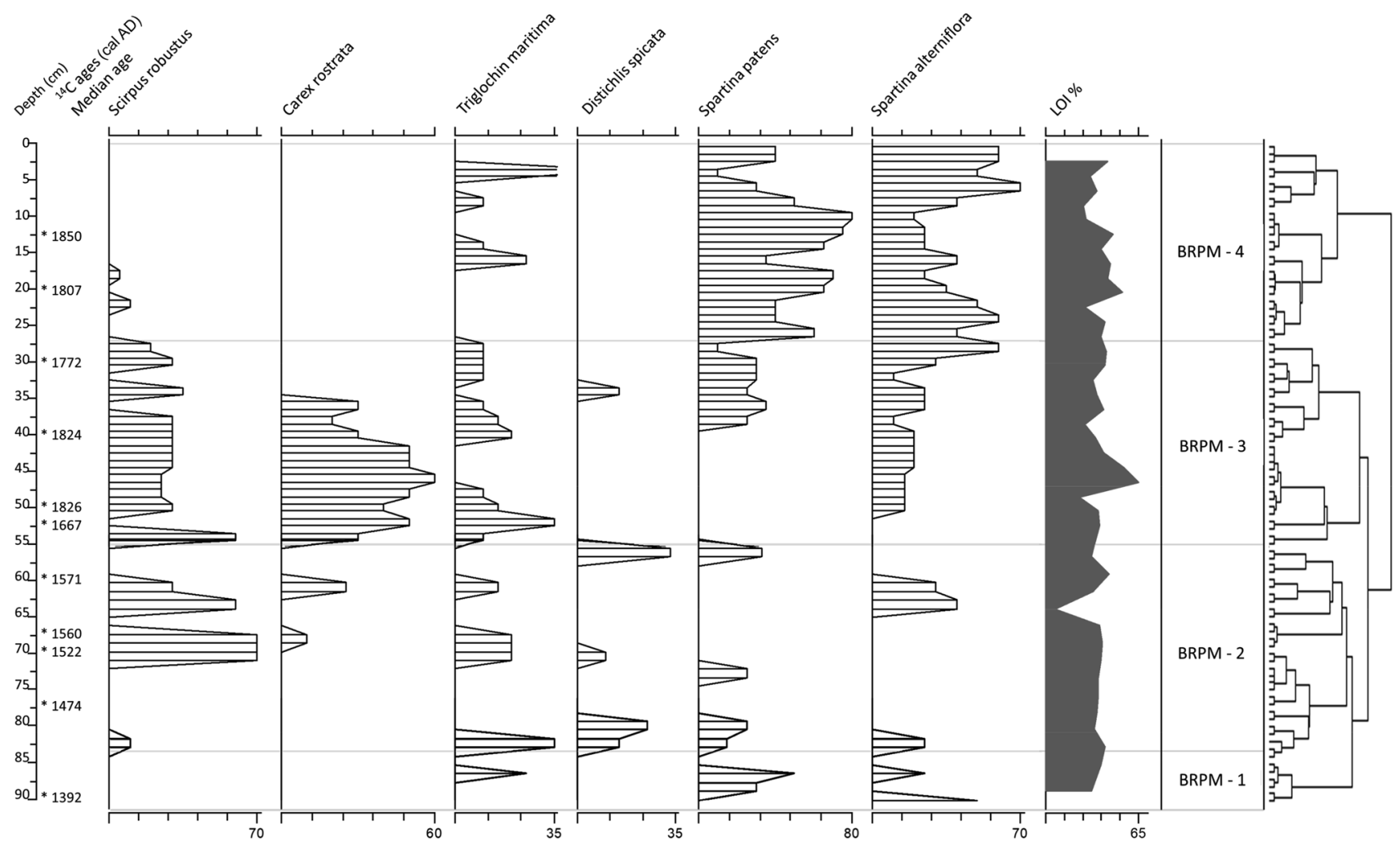

Fig. 5 Plant macrofossil diagram from Big River Marsh core BRM1 
Table 3 Pollen zone descriptions for upland pollen, wetland pollen and plant macrofossils

\begin{tabular}{|c|c|c|c|}
\hline Zone & Depth $(\mathrm{cm})$ & $\begin{array}{l}\text { Median }{ }^{14} \mathrm{C} \text { age } \\
\text { range (cal } \mathrm{AD})\end{array}$ & Zone description \\
\hline \multicolumn{4}{|c|}{ Upland pollen zones } \\
\hline BRU-3 & $0-12$ & Post 1850 & $\begin{array}{l}\text { High levels of Picea (up to } 42 \% \text { ) and Corylus (hazel) (up to } 21 \% \text { ) and moderate levels of Alnus pol- } \\
\text { len (up to } 17 \% \text { ). Betula pollen decreases throughout the zone, making up } 40 \% \text { of upland pollen at } \\
11 \mathrm{~cm} . \text { Plantago lanceolata (ribwort plantain) peaks at } 7 \mathrm{~cm} \mathrm{(23 \% ).} \mathrm{Charcoal} \mathrm{fragments} \mathrm{achieve} \\
0.65 \mathrm{~cm}^{-3} \text { at the top of the profile }\end{array}$ \\
\hline BRU-2 & $12-74$ & $1500-1850$ & $\begin{array}{l}\text { High levels of Picea (up to 62\%), Betula (up to 47\%) and Corylus pollen (up to 29\%). Alnus peaks at } \\
21 \mathrm{~cm}(29 \%) \text { and a second peak in P. lanceolata occurs at } 15 \mathrm{~cm}(23 \%)\end{array}$ \\
\hline BRU-1 & $74-88$ & $1375-1500$ & $\begin{array}{l}\text { High levels of Betula (up to } 43 \% \text { ) and Picea pollen (up to } 41 \% \text { ) with subsidiary Alnus (up to } 14 \% \text { ) } \\
\text { and Carya (hickory) (up to } 11 \% \text { ). There are peaks in Plantago pollen }(25 \% \text { at } 84 \mathrm{~cm} \text { ), Asteraceae } \\
\text { tubuliflorae ( } 15 \% \text { at } 75 \mathrm{~cm} \text { ) and charcoal fragments at } 80 \mathrm{~cm} \text {. Maximum Corylus percentages occur } \\
\text { in the upper part of the zone }(59 \%)\end{array}$ \\
\hline \multicolumn{4}{|c|}{ Wetland pollen zones } \\
\hline BRW-3 & $0-30$ & 1750 -post 1850 & $\begin{array}{l}\text { High levels of Potamogeton pollen (up to } 47 \% \text { ), although values decline to } 2 \% \text { at } 23 \mathrm{~cm} \text {. Moderate } \\
\text { levels of Poaceae pollen (up to 18\%). Filicales spores reach } 8 \% \text { at } 5 \mathrm{~cm} \text {. Caryophyllaceae pollen } \\
\text { levels reach } 6 \% \text { at } 9 \mathrm{~cm}\end{array}$ \\
\hline BRW-2 & $30-52$ & $1500-1850$ & $\begin{array}{l}\text { High levels of Cyperaceae (up to } 45 \% \text { ). Low percentages of Potamogeton (pondweed) }(\leq 6 \%) \text {. Low- } \\
\text { est pollen concentrations of the profile at } 45 \mathrm{~cm} \text {. Highest concentrations of Foraminifera (up to } \\
0.24 \mathrm{~cm}^{-3} \text { ) and Glomus spores (up to } 0.1 \mathrm{~cm}^{-3} \text { ) }\end{array}$ \\
\hline BRW-1 & $52-88$ & $1375-1500$ & $\begin{array}{l}\text { High pollen concentrations (up to } 59,155 \mathrm{~cm}^{-3} \text { ). Poaceae levels decrease throughout the zone. Fluc- } \\
\text { tuating levels of Potamogeton reach a high of } 40 \% \text { at the top of the zone }\end{array}$ \\
\hline \multicolumn{4}{|c|}{ Plant macrofossil zones } \\
\hline BRPM-4 & $0-26$ & 1800 -post 1850 & $\begin{array}{l}\text { Spartina patens (up to 80\%) and Spartina alterniflora (up to 70\%) reach peak abundance. There are } \\
\text { fluctuating levels of Triglochin maritima throughout the upper zone }\end{array}$ \\
\hline BRPM-3 & $26-54$ & $1600-1850$ & $\begin{array}{l}\text { High levels of Carex rostrata (bottle sedge) in the lower to mid zone, reaching peak profile abun- } \\
\text { dance (up to 60\%), but disappearing from the profile above } 35 \mathrm{~cm} \text {. High levels of Scirpus robustus } \\
\text { (seacoast bulrush) in the lower zone (reaching } 60 \% \text { at } 54 \mathrm{~cm} \text { ), with fluctuating levels throughout } \\
\text { the mid to upper zone. Spartina patens and S. alterniflora increase in the upper zone. Fluctuating } \\
\text { levels of Triglochin maritima throughout }\end{array}$ \\
\hline BRPM-2 & $54-83$ & $1450-1600$ & $\begin{array}{l}\text { S. robustus reaches peak abundance (up to } 70 \%) \text { where } S \text {. alterniflora rootlets are absent between } 59 \\
\text { and } 52 \mathrm{~cm} \text {. Distichlis spicata peaks }(33 \%) \text { at } 56 \mathrm{~cm} \text { to } 57 \mathrm{~cm} \text {. Plant macrofossils are absent from } \\
\text { some horizons }(58 \mathrm{~cm}, 59 \mathrm{~cm}, 64 \mathrm{~cm}, 65 \mathrm{~cm}, 72-75 \mathrm{~cm}, 80 \mathrm{~cm} \text { and } 81 \mathrm{~cm} \text { ) }\end{array}$ \\
\hline BRPM-1 & $83-90$ & $1375-1450$ & High levels of S. alterniflora (50\%) and S. patens $(20 \%)$ \\
\hline
\end{tabular}

Fig. 6 Cyperaceae and Poaceae pollen and plant macrofossil diagram for Big River Marsh core BRM1, shown alongside the Foraminifera-derived reconstruction of palaeo-marsh elevation in standardised water level index (F-SWLI) units, where a value of 100 corresponds to mean tide level and 200 is the highest occurrence of Foraminifera (from Kemp et al. 2018)

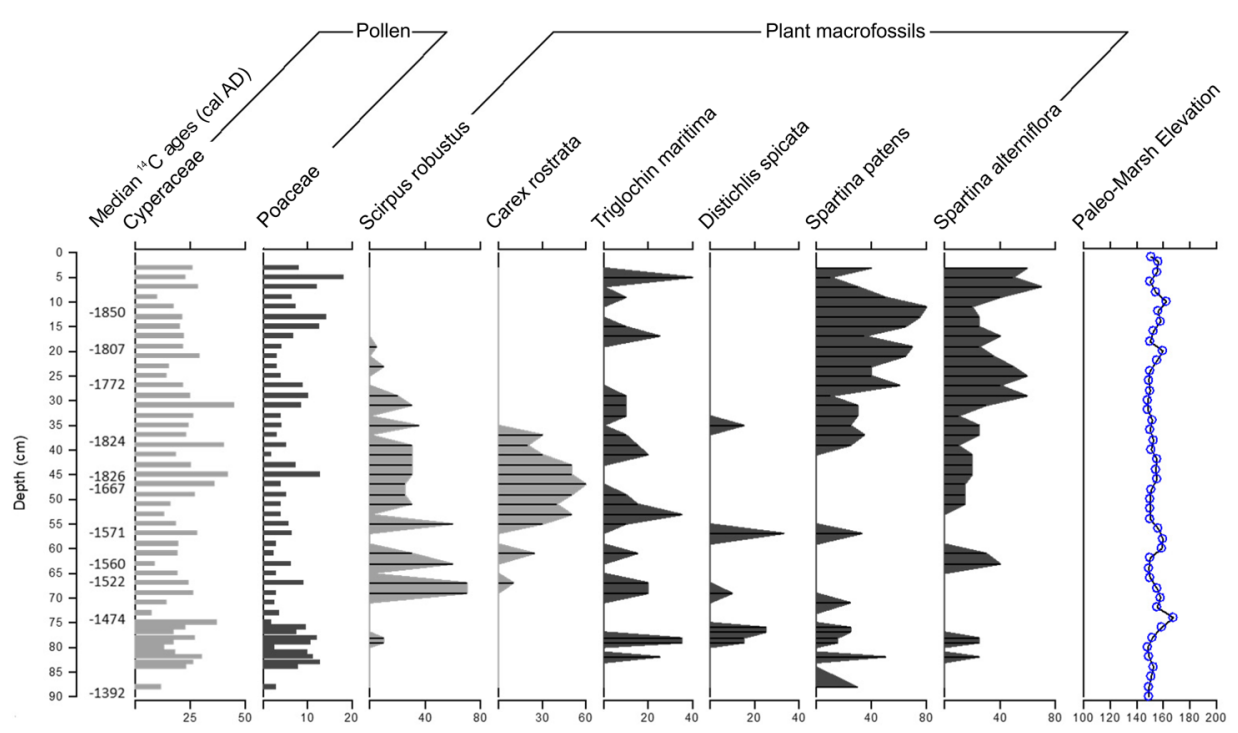


transported via water (Patterson III et al. 1987; Schmidt and Noack 2000; Lindskoug and Marconetto 2019). The increase in fragment concentration in BRM1 may therefore not necessarily represent anthropogenic presence in the Port au Port region, but instances of increased wildfire, site exposure and hydrological change, particularly as peaks in microcharcoal fragments are evident from at least ca. AD 1500 at Big River Marsh.

Fluctuations in tree pollen values could also be associated with phases of hemlock looper outbreak. Arsenault et al. (2016) cite defoliating insects as the cause of the largest disturbance footprints in Newfoundland. Outbreaks are thought to occur approximately every $10-12$ years in Newfoundland (Iqbal et al. 2011). Mortality levels of A. balsamea are found to be particularly affected by the defoliator, although a variety of other coniferous and deciduous trees are susceptible (Iqbal et al. 2011).

\section{Upland pollen representation}

Upland pollen is typically deposited on saltmarshes from a wide catchment area via a range of dispersal mechanisms, including from the hinterland of the saltmarsh (wind-dispersed), the river catchment (fluvial) and via marine tidal processes (Chmura and Eisma 1995; Roe and van de Plassche 2005; Dai et al. 2014). The upland pollen assemblage of the saltmarsh sediments at Big River Marsh are dominated by high levels of tree and shrub pollen, including Picea (up to $45 \%$ ), Betula (up to $26 \%$ ) and Corylus (up to $28 \%$ ) pollen, with lesser amounts of Alnus (up to 18\%), and fluctuating levels of herbaceous pollen. Abies pollen values are relatively low throughout the assemblage $(<3 \%)$. Pinus levels are also low $(<5 \%)$, despite the presence of the taxon in the hinterland of the modern marshland.

The high Betula pollen values and low Abies pollen levels at Big River Marsh are unlikely to represent the proportion of the taxa present in the landscape. A. balsamea is a dominant species in Western Newfoundland and is thought to be greatly under-represented in regional pollen records, while Betula, which is also a dominant regional species, is often over-represented (Brown Macpherson 1995; Jessen et al. 2011). Pinus is also often over-represented in pollen records, particularly in exposed coastal areas where pollen can travel from long distances via wind and marine water dispersal with minimal interception (Heusser 1983; Brown Macpherson 1995; Williams 2010). However, the low Pinus pollen values at Big River Marsh may indicate under-representation of the taxon, as pollen from the hinterland is able to spread over a wider distance via the southwest prevailing wind direction (Mudie and McCarthy 1994). Picea species are thought to be well-represented in modern regional pollen records and make up approximately $46 \%$ of the forest composition in southwest Newfoundland, indicating that the high values recorded at Big River Marsh may be representative of Picea presence in the surrounding landscape (Brown Macpherson 1995).

\section{Saltmarsh vegetation changes}

The wetland pollen and spore record indicates the continuous presence of saltmarsh vegetation, with a dominance of Cyperaceae and fluctuating levels of Poaceae pollen throughout, consistent with the pollen record from Hynes Brook Marsh (Brookes et al. 1985). Variable levels of Potamogeton pollen indicate the presence of standing or very slow moving water near to the core site (Clapham et al. 1987). The plant macrofossil assemblage provides a high resolution record of saltmarsh vegetation changes, with evidence for a significant phase of Cyperaceae expansion and subsequent retreat, possibly driven by local hydrological changes and a general shift towards an intermediate marsh vegetation composition as sea-level rise began to accelerate from ca. AD 1700 (Kemp et al. 2018).

Ca. AD 1392-1667: From ca. AD 1392, the plant macrofossil assemblage indicates that the marsh surface was populated by low and high marsh vegetation, signified by the presence of Triglochin maritima and common saltmarsh grass species including Spartina patens, S. alterniflora and Distichlis spicata (Clapham et al. 1987; Bertness 1991). At ca. $\mathrm{AD} 1474(75-71 \mathrm{~cm})$, there is a break in the plant macrofossil record, which coincides with a peak in the Foraminiferaderived reconstruction of palaeo-marsh elevation at $74 \mathrm{~cm}$. The associated sediment-dominated layer is characterised by an increase in shrub pollen and coincides with a significant reduction in Poaceae and Cyperaceae pollen and a subsequent increase in Potamogeton pollen. These changes could have resulted from a short-lived increase in local sea level. This may have been associated with marsh erosion and sediment deposition, possibly driven by catchment flooding, tectonic subsidence, a storm or a tsunami which carried arboreal (shrub) pollen into the site, or a localised phase of ponding. There are also two thinner horizons $(65-63 \mathrm{~cm}$ and $59-57 \mathrm{~cm}$ ) at ca. AD 1550 and 1571 where there is a break in the plant macrofossil record. LOI levels fall significantly at $63 \mathrm{~cm}(6.3 \%)$, although a corresponding environmental response in the pollen record is less evident. The horizons may correspond with observations made by Kemp et al. (2018), where the presence of bands of fine-grained clastic sediments are noted in the stratigraphy at Big River Marsh, and are assigned to either the development of pools of water on the marsh or the delivery of ice-rafted sediments. The close proximity of the coring site to the main Big River channel (approximately $20 \mathrm{~m}$ ) (Fig. 1) and to salt pannes on the contemporary marsh surface, indicate the possibility of flooding and/or salt panne development of the coring site. 
From ca. AD 1500 a period of marine regression is indicated by an increase in the upper marsh species Scirpus robustus and Carex rostrata (Clapham et al. 1987; Wang et al. 2004). A brief phase of marine transgression is apparent as D. spicata and S. alterniflora increase in abundance at ca. AD 1600, before a sharp increase in S. robustus rootlets, Potamogeton pollen and overall pollen concentrations indicates a return to upper marsh conditions and increased areas of freshwater seepage in the upper marsh. The brief phases of fluctuating RSL in this period are not reflected in the reconstruction of RSL at Big River Marsh by Kemp et al. (2018), although the reconstruction of global mean sea level does show fluctuation in this period, potentially indicating eustatic changes.

Ca. AD 1667-1772: From ca. AD 1667, the prevalence of $C$. rostrata remains, a fresh-water sedge which inhabits inundated areas, alongside $S$. robustus and high Cyperaceae pollen levels, indicate that an upper marsh habitat prevailed (Barnett et al. 2017). The presence of T. maritima remains and Foraminifera in some horizons at this time indicate that the site continued to be impacted by tidal inundation. Glomus spore abundance is also high in this period and has some correlation with the rootlet percentages of $T$. maritima. Increased Glomus spore abundance may reflect periods of increased germination in response to increased marsh salinity (Carvalho et al. 2004). Prior to ca. AD 1772, the decline in $C$. rostrata rootlet abundance, alongside an increase in S. alterniflora and S. patens remains, suggests a transition phase on the marsh, with the presence of upper, high and low marsh species.

Post ca. AD 1772: From ca. AD 1772, the wetland pollen assemblage indicates a reduction in Cyperaceae abundance and an increase in areas of standing water on the marsh surface as Potamogeton pollen levels increase. Increased ponding could be attributed to the effects of local rising sea-levels, which can affect the mortality of both saltwater and waterlogging intolerant vegetation and lead to the development of depressions in the marsh in places of vegetation die-back (DeLaune et al. 1994; Brownstein et al. 2013; Raposa et al. 2017). S. patens and S. alterniflora dominate the plant macrofossil assemblage in this period, alongside fluctuating levels of T. maritima, indicating high and low marsh zonation and a similar vegetation composition to present day. S. alterniflora and T. maritima become more dominant from $7 \mathrm{~cm}$, indicating a continuous rise in sea-level. Collectively, increased marsh surface ponding and the apparent transition to a high/low marsh vegetation composition indicates accelerated RSL in this period. The age-depth model and relative sea-level curve for Big River Marsh (Kemp et al. 2018) also indicate an apparent $\mathrm{AD} \sim 1700$ acceleration in the rate of marsh-surface accumulation, concurrent with late Holocene sea level studies of Atlantic Canada (Gehrels et al. 2005; Barnett et al. 2017) and the wider NW Atlantic region (Billy et al. 2015; Kemp et al. 2015, 2018). The palaeo-marsh elevation curve shows that marsh surface elevation was largely able to keep pace with the inferred RSL rise in the period since $\mathrm{AD} \sim 1700$ (Kemp et al. 2018).

\section{Wetland pollen representation}

Studies of wetland pollen representation often assume that the pollen derives from vegetation located within approximately two metres of the sampling site (Bunting 2003; Pendea and Chmura 2012; García-Moreiras et al. 2015). Roe and van de Plassche (2005) found that the primary control on wetland pollen representation of the saltmarsh surface is the proximity of the sediments to the source vegetation. The modern vegetation composition of Big River Marsh is typical of many saltmarshes in the region (e.g. Edwards et al. 2004; Byers and Chmura 2007; Coulombier et al. 2012), with Cyperaceae species in the upper marsh and the transition to high and low marsh areas marked by a dominance of saltmarsh Poaceae species. However, an apparent bias towards pollen derived from the upper marsh areas is evident throughout the wetland pollen assemblage at Big River Marsh, showing a dominance of Cyperaceae (up to 45\%) and fluctuating levels of Potamogeton (up to $48 \%)$ throughout, while Poaceae pollen accounts for only 2 to $18 \%$ of the pollen counted. Roe and van de Plassche (2005) and Pendea and Chmura (2012) found similar results when analysing surface saltmarsh sediments, with proximate Cyperaceae vegetation well-represented in the pollen record, whilst Poaceae dominated areas of the saltmarsh were less well-represented. This may be a consequence of differences in pollen dispersal, morphological characteristics of the source vegetation or geomorphological characteristics of the marsh area from which the pollen was derived. Frequently flooded marsh areas can also be susceptible to tidal influxes or transfers of pollen away from the marsh, which may have a differential effect on high and low marsh areas dominated by Poaceae species compared to the Cyperaceae dominated upper marsh (Medeanic et al. 2016). Influxes of wetland pollen from other coastal areas could lead to relative under-representation of Poaceae pollen, whilst the transfer of pollen away from the marsh will reduce the concentration of pollen from high and low marsh areas. Cyperaceae pollen, which has high dispersibility (Fontana 2005) may also be transferred from the upper marsh to high and low marsh areas via southwest prevailing winds, leading to the potential over-representation of the vegetation in the pollen record at Big River Marsh. 


\section{Plant macrofossil representation}

Comparison of the wetland pollen and plant macrofossil assemblages illustrates differential representation of the abundance and spatial distribution of saltmarsh vegetation on the marsh surface, highlighting the benefit of utilising both analysis methods. The plant macrofossil assemblage for BRM1 generally shows fluctuations between sediments dominated by the remains of Cyperaceae species and Poaceae dominated peats. However, understanding the relationship between Cyperaceae vegetation abundance and pollen abundance is more complex, with Cyperaceae pollen levels remaining high where no macrofossil remains are present, and remaining low at times where the macrofossil remains of Cyperaceae species peak. The absence of Cyperaceae plant macrofossil remains where the pollen levels are relatively high (e.g. below $80 \mathrm{~cm}$ ) could reflect an initial expansion of Cyperaceae communities on the fringes of the marsh during a period of relative sea-level fall or stable sea levels. Cyperaceae pollen could also have been derived from adjacent areas of standing water.

The apparent delay in Cyperaceae pollen production relative to macrofossil abundance in the lower ca. $30 \mathrm{~cm}$ of the core may reflect Cyperaceae rhizome encroachment across the marsh during a period of stable sea levels, marine regression or a phase of enhanced freshwater seepage, possibly driven by climate change or other local hydrological changes. Cyperaceae rhizomes can extend away from swards on the fringes of marshes, resulting in the presence of belowground biomass before pollen-producing above-ground biomass develops. This would generate Cyperaceae rhizome plant macrofossil remains in sediments prior to the dispersal of Cyperaceae pollen.

It is notable that Juncaginaceae is absent from the pollen record, despite T. maritima constituting a large proportion of the plant macrofossil assemblage. Juncaginaceae pollen, being produced by anemophilous plants, has a high transport capacity (Pires and Medeanic 2006). It is possible that underrepresentation of the taxa in the pollen record could be attributed to dispersal of the pollen away from the parent vegetation to other areas of the marsh or further afield.

Despite the under-representation of Poaceae species in the pollen record, there is a correspondence between the relative abundance of Poaceae pollen and plant macrofossil remains. Correspondence between the Poaceae pollen curve and the S. alterniflora plant macrofossil profile indicates that the species is particularly well-represented.

\section{Chronozones and RSL}

The saltmarsh sediments from the Big River Marsh BRM1 core provide a high resolution, well-dated record of recent vegetation, environmental and sea-level change around the site. Analysis of the upland pollen record allows landscapescale changes to be established, including regional forest fire events and inferred phases of increased human presence in the area, which have the potential to be applied as pollen markers for dating the saltmarsh core. The wide radiocarbon age range in the upper sediments of the core reiterates the importance of applying a complementary dating proxy for reconstructing saltmarsh accumulation rates. The concurrence of radiocarbon dates from the upper core and signals of anthropogenic disturbance in the pollen record and dated documentary accounts of increased human presence in the region, indicate the relative accuracy of the two chronozones identified, though anthropogenic markers are subtle. The first chronozone is represented by a peak in Plantago lanceolata pollen levels around the late 1700s, alongside a small increase in Ambrosia, and corresponds with a period of sedentary occupation by the Mi'kmaq people of St. George's Bay, and European settlement of the area at the end of the 18th century. The second chronozone is represented by a second peak in P. lanceolata and a small increase in Rumex pollen levels following increased seasonal and permanent settlement of the Port au Port peninsula in the mid 1800s. Earlier signals of anthropogenic disturbance from the 1400s could be attributed to the presence of ancestors of the Beothuk, whose presence in the area is indicated in the local archaeological record (Simpson 1986). With further regional palynological and archaeological research there may be the potential to develop a third chronozone associated with the withdrawal of ancestral Beothuk populations in the area. There is some indication of reforestation in the early 1600s in the landscape surrounding Big River Marsh which may be a signal of a local depopulation event which is thought to have commenced in the 1400s throughout North America (Liebmann et al. 2016). Pollen records from the late Holocene in Newfoundland indicate a late increase in some arboreal pollen levels which may also be an indication of such an event (e.g. Brookes et al. 1985; Brown Macpherson 1995). Correlation of dated late Holocene pollen records in the region may generate a greater understanding of the population dynamics and land usage of the ancestral Beothuk people and allow earlier pollen chronozones to be developed.

The wetland vegetation record indicates phases of localised hydrological change in the saltmarsh and changes in RSL. Generally, the wetland pollen and plant macrofossil records indicate a transition from a high/upper marsh vegetation composition to a high/low marsh vegetation from ca. 1772. However, there are prior subtle fluctuations in RSL which are not reflected in regional coarser-scale studies (e.g. Daly et al. 2007; Kemp et al. 2018). High resolution studies of recent saltmarsh accumulation rate changes through pollen, macrofossil and Foraminifera analyses, combined with chronozone dating may further increase the understanding of the drivers of RSL in Newfoundland. 


\section{Conclusions}

Saltmarsh sediments are often a successful source of well-preserved pollen and plant macrofossil remains from the late Holocene. However, there is a need for additional chronological information to increase knowledge of anthropogenic activities in the Port au Port region of Newfoundland and aid the precision of RSL inferences. The wide radiocarbon age range demonstrated in the upper sediments of the saltmarsh core analysed by Kemp et al. (2018) at Big River Marsh, reiterates the importance of applying a complementary dating proxy for reconstructing saltmarsh accumulation rates. Detailed analysis of the upland and wetland pollen, non-pollen palynomorph record (foraminiferal linings and fungal spores) and plant macrofossil remains of the sediments sampled at Big River Marsh produces a high resolution, well-dated recent relative sea-level, wetland vegetation and landscape change record of the site. Grouping the pollen record into upland and wetland assemblages allows local events related to hydrological change to be separated from landscape-scale changes. The upland pollen record is dominated by Picea and Betula tree pollen and corresponds well with regional pollen records from the same period. Picea is thought to be well-represented in the assemblage whilst Abies, which is a dominant species in region, and Pinus are deemed as under-represented. Betula is thought to be over-represented in the pollen record compared to regional records of species abundance. Two potential chronozones have been identified in the upland assemblage, the first represented by a peak in Plantago lanceolata pollen levels around the late 1700s, alongside a small increase in Ambrosia. The changes potentially correspond with a period of sedentary occupation by the Mi'kmaq people of St. George's Bay, and European settlement of the area at the end of the 18th century. The second chronozone is represented by a second peak in P. lanceolata and a small increase in Rumex pollen levels following increased seasonal and permanent settlement of the Port au Port peninsula in the mid 1800s. However, historic pollen markers are not as well developed at Big River Marsh compared to other records in the North Atlantic region (e.g. Fuller et al. 1998; Paquette and Gajewski 2013) and should be treated with caution. Similarly, there are no notable peaks in micro-charcoal fragments which can be reliably distinguished from natural forest-fire events.

The wetland pollen record shows an apparent underrepresentation of Poaceae pollen, whilst Cyperaceae and Potamogeton pollen are often abundant throughout the assemblage. The wetland pollen and plant macrofossil record indicate changes in local sea-level, generally showing accelerated rise from ca. AD 1700. The representation of Cyperaceae macrofossil remains in the wetland pollen profile is complex, showing a vertical off-set thought to be related to rhizome encroachment from the marsh fringe during periods of marine regression. Correspondence between the Poaceae pollen curve and the S. alterniflora plant macrofossil profile indicates that the species is particularly well-represented in the plant macrofossil record. Comparison of the plant macrofossil and wetland pollen profiles highlights the need for further analysis of the zonation, pollen dispersal and macrofossil representation of Cyperaceae species in saltmarshes. Future studies using plant macrofossils should distinguish between the bulbs, rhizomes, roots and stems of Cyperaceae to increase the information obtained.

Acknowledgements We thank the Department of Earth Sciences, Vrije University Amsterdam for assistance with the preparation of pollen samples. KS, HR and AW acknowledge the inspirational leadership provided by co-author Orson van de Plassche, a meticulous and energetic field scientist and leading sea-level researcher who passed away in 2009 .

Author contributions KS, HR and OvdP designed the study; KS and AW undertook the pollen and plant macrofossil analyses and HR assisted with data plotting. OvdP secured funding, provided logistical support and access to laboratory facilities at the Vrije University for sample processing. The write up and figures were completed by KS, $\mathrm{HR}$ and SD.

Funding The Foraminifera-derived sea-level research associated with this study (published by Kemp et al. 2018) was supported by a grant from the Netherlands to OvdP and is gratefully acknowledged.

\section{Declarations}

Conflict of interest All authors declare that they have no conflict of interest.

Open Access This article is licensed under a Creative Commons Attribution 4.0 International License, which permits use, sharing, adaptation, distribution and reproduction in any medium or format, as long as you give appropriate credit to the original author(s) and the source, provide a link to the Creative Commons licence, and indicate if changes were made. The images or other third party material in this article are included in the article's Creative Commons licence, unless indicated otherwise in a credit line to the material. If material is not included in the article's Creative Commons licence and your intended use is not permitted by statutory regulation or exceeds the permitted use, you will need to obtain permission directly from the copyright holder. To view a copy of this licence, visit http://creativecommons.org/licenses/by/4.0/.

\section{References}

Anderson TW (1974) The chestnut pollen decline as a time horizon in lake sediments in eastern North America. Can J Earth Sci 11:678-685 
Arsenault A, LeBlanc R, Earle E, Brooks D, Clarke B, Lavigne D, Royer L (2016) Unravelling the past to manage Newfoundland's forests for the future. Forestry Chronicle 92:487-502

Barber K-E (1976) History of Vegetation. In: Chapman SB (ed) Methods in plant ecology. Blackwell Scientific Publications, Oxford, pp 5-83

Barlow NLM, Shennan I, Long AJ, Gehrels WR, Saher MH, Woodroffe SA, Hillier C (2013) Salt marshes as late Holocene tide gauges. Glob Planet Chang 106:90-110

Barnett RL, Garneau M, Bernatchez P (2016) Salt-marsh sea-level indicators and transfer function development for the Magdalen Islands in the Gulf of St. Lawrence, Canada. Marine Micropalaeontol 122:13-26

Barnett RL, Bernatchez P, Garneau M, Juneau M-N (2017) Reconstructing late Holocene relative sea-level changes at the Magdalen Islands (Gulf of St. Lawrence, Canada) using multi-proxy analyses. J Quat Sci 32:380-395

Barter G (1986) A linguistic description of the French spoken on the Port-au-Port peninsula of western Newfoundland. Doctoral dissertation, Memorial University of Newfoundland, St. John's

Batterson M, Liverman D (2010) Past and future sea-level change in Newfoundland and Labrador: Guidelines for policy and planning. Current Research: Newfoundland and Labrador Department of Natural Resources Geological Survey, Report 10-1, pp 129-141

Bégeot C (1998) Pollen behaviour of Hazelnut (Corylus avellana), an indicator of human impacts? One example along a transect in Southern French Jura. Acta Bot Gallica 145:271-279

Bell T, Daly J, Batterson MJ, Liverman DGE, Shaw J, Smith IR (2005) Late Quaternary relative sea-level change on the west coast of Newfoundland. Géogr Phys Quat 59:129-140

Bertness MD (1991) Zonation of Spartina patens and Spartina alterniflora in New England salt marsh. Ecology 72:138-148

Billy J, Robin N, Hein CJ, Certain R, FitzGerald DM (2015) Insight into the late Holocene sea-level changes in the NW Atlantic from a paraglacial beach-ridge plain south of Newfoundland. Geomorphology 248:134-146

Blaauw M (2010) Methods and code for 'classical' age-modelling of radiocarbon sequences. Quat Geochronol 5:512-518

Blarquez O, Talbot J, Paillard J, Lapointe-Elmrabti L, Pelletier N, StPierre CG (2018) Late Holocene influence of societies on the fire regime in southern Québec temperate forests. Quat Sci Rev 180:63-74

Blundell A, Hughes PDM, Chambers FM (2018) An 8000-year multiproxy peat-based palaeoclimate record from Newfoundland: evidence of coherent changes in bog surface wetness and ocean circulation. Holocene 28:791-805

Brain MJ, Kemp AC, Horton BP, Culver SJ, Parnell AC, Cahill N (2015) Quantifying the contribution of sediment compaction to late Holocene salt-marsh sea-level reconstructions, North Carolina, USA. Quat Res 83:41-51

Brookes IA, Scott DB, McAndrews JH (1985) Postglacial relative sealevel change, Port au Port area, west Newfoundland. Can J Earth Sci 22:1,039-1,047

Brown MacPherson J (1995) A $6 \mathrm{ka}$ BP reconstruction for the island of Newfoundland from a synthesis of Holocene lake-sediment pollen records. Géogr Phys Quat 49:163-182

Brownstein G, Wilson JB, Burritt DJ (2013) Waterlogging tolerance on a New Zealand saltmarsh. J Exp Mar Biol Ecol 446:202-208

Brugam RB (1978) Pollen indicators of land-use change in southern Connecticut. Quat Res 9:349-362

Bunting MJ (2003) Pollen-vegetation relationships in non-arboreal moorland taxa. Rev Palaeobot Palynol 125:285-298

Butt J (2017) Port au Port Peninsula. https://www.heritage.nf.ca/artic les/society/port-au-port-peninsula.php. Accessed 20 April 2020
Byers SE, Chmura GL (2007) Salt marsh vegetation recovery on the Bay of Fundy. Estuar Coasts 30:869-877

Carvalho LM, Correia PM, Martins-Loução MA (2004) Arbuscular mycorrhizal fungal propagules in a salt marsh. Mycorrhiza 14:165-170

Chmura GL, Eisma D (1995) A palynological study of surface and suspended sediments on a tidal flat: implications for pollen transport and deposition in coastal waters. Mar Geol 128:183-200

Clapham AR, Tutin TG, Moore DM (1987) Flora of the British Isles, 3rd edn. Cambridge University Press, Cambridge

Clark RL (1982) Point count estimation of charcoal in pollen preparations and thin sections of sediments. Pollen Spores 24:523-535

Coulombier T, Neumeier U, Bernatchez P (2012) Sediment transport in a cold climate salt marsh (St. Lawrence Estuary, Canada), the importance of vegetation and waves. Estuar Coast Shelf Sci 101:64-75

Dai L, Weng C, Lu J, Mao L (2014) Pollen quantitative distribution in marine and fluvial surface sediments from the northern South China Sea: new insights into pollen transportation and deposition mechanisms. Quat Int 325:136-149

Daly JF, Belknap DF, Kelley JT, Bell T (2007) Late Holocene sea-level change around Newfoundland. Can J Earth Sci 44:1,453-1,465

DeLaune RD, Nyman JA, Patrick WH Jr (1994) Peat collapse, ponding and wetland loss in a rapidly submerging coastal marsh. J Coast Res 10:1,021-1,030

Edwards RJ, Wright AJ, van de Plassche O (2004) Surface distributions of salt-marsh foraminifera from Connecticut, USA: modern analogues for high-resolution sea level studies. Mar Micropalaeontol 51:1-21

Faegri K, Iversen J (1989) In: Faegri K, Kaland PE, Krzywinski K (eds) Textbook of pollen analysis, 4th edn. Wiley, Chichester

Finsinger W, Tinner W, van der Knaap WO, Ammann B (2006) The expansion of hazel (Corylus avellana L.) in the southern Alps: a key for understanding its early Holocene history in Europe? Quat Sci Rev 25:612-631

Fontana SL (2005) Coastal dune vegetation and pollen representation in south Buenos Aires Province, Argentina. J Biogeogr 32:719-735

Fuller JL, Foster DR, McLachlan JS, Drake N (1998) Impact of human activity on regional forest composition and dynamics in central New England. Ecosystems 1:76-95

García-Moreiras I, Sánchez JM, Muñoz Sobrino C (2015) Modern pollen and non-pollen palynomorph assemblages of salt marsh and subtidal environments from the Ría de Vigo (NW Iberia). Rev Palaeobot Palynol 219:157-171

Gehrels WR (2000) Using foraminiferal transfer functions to produce high-resolution sea-level records from salt-marsh deposits, Maine, USA. Holocene 10:367-376

Gehrels WR, Roe HM, Charman DJ (2001) Foraminifera, testate amoebae and diatoms as sea-level indicators in UK saltmarshes: a quantitative multiproxy approach. J Quat Sci 16:201-220

Gehrels WR, Milne GA, Kirby JR, Patterson RT, Belknap DF (2004) Late Holocene sea-level changes and isostatic crustal movements in Atlantic Canada. Quat Int 120:79-89

Gehrels WR, Kirby JR, Prokoph A et al (2005) Onset of recent rapid sea-level rise in the western Atlantic Ocean. Quat Sci Rev 24:2,083-2,100

Hayward BW, Scott GH, Grenfell HR, Carter R, Lipps JH (2004) Techniques for estimation of tidal elevation and confinement ( $\sim$ salinity) histories of sheltered harbours and estuaries using benthic foraminifera: examples from New Zealand. Holocene 14:218-232

Heiri O, Lotter AF, Lemcke G (2001) Loss on ignition as a method for estimating organic and carbonate content in sediments: reproducibility and comparability of results. J Palaeolimnol 25:101-110

Heusser LE (1983) Pollen distribution in the bottom sediments of the western North Atlantic Ocean. Mar Micropalaeontol 8:77-88 
Holly DH Jr, Wolff CB, Erwin JC (2015) Before and after the fire: archaeological investigations at a Little Passage/Beothuk encampment in Trinity Bay, Newfoundland. Can J Archaeol 39:1-30

IPCC (2019) Summary for policymakers. In: Pörtner H-O, Roberts DC, Masson-Delmotte V et al (eds) IPCC special report on the ocean and cryosphere in a changing climate. Intergovernmental Panel on Climate Change, Geneva

Iqbal J, MacLean DA, Kershaw JA Jr (2011) Impacts of hemlock looper defoliation on growth and survival of balsam fir, black spruce and white birch in Newfoundland, Canada. For Ecol Manag 261:1,106-1,114

Ireland AW, Clifford MJ, Booth RK (2014) Widespread dust deposition on North American peatlands coincident with European land-clearance. Veget Hist Archaeobot 23:693-700

Jessen CA, Solignac S, Nørgaard-Pedersen N, Mikkelsen N, Kuijpers A, Seidenkrantz MS (2011) Exotic pollen as an indicator of variable atmospheric circulation over the Labrador Sea region during the mid to late Holocene. J Quat Sci 26:286-296

Juggins S (2007) C2 Version 1.5 User guide. Software for ecological and palaeoecological data analysis and visualisation. Newcastle University, Newcastle upon Tyne

Juggins S (2017) rioja: Analysis of Quaternary Science Data, R package version (0.9-21). http://cran.r-project.org/package $=$ rioja

Kemp AC, Horton BP, Culver SJ et al (2009) Timing and magnitude of recent accelerated sea-level rise (North Carolina, United States). Geology 37:1,035-1,038

Kemp AC, Horton BP, Donnelly JP, Mann ME, Vermeer M, Rahmstorf S (2011) Climate related sea-level variations over the past two millennia. Proc Natl Acad Sci USA 108:11,017-11,022

Kemp AC, Bernhardt CE, Horton BP et al (2014) Late Holocene seaand land-level change on the U.S. southeastern Atlantic coast. Mar Geol 357:90-100

Kemp AC, Hawkes AD, Donnelly JP et al (2015) Relative sea-level change in Connecticut (USA) during the last 2200 yrs. Earth Planet Sci Lett 428:217-229

Kemp AC, Wright AJ, Barnett RL et al (2017) Utility of salt-marsh foraminifera, testate amoebae and bulk-sediment $\delta^{13} \mathrm{C}$ values as sea-level indicators in Newfoundland, Canada. Mar Micropalaeontol 130:43-59

Kemp AC, Wright AJ, Edwards RJ et al (2018) Relative sea-level change in Newfoundland, Canada during the past $\sim 3000$ years. Quat Sci Rev 201:89-110

Kujawa ER, Goring S, Dawson A et al (2016) The effects of anthropogenic land cover change on pollen-vegetation relationships in the American Midwest. Anthropocene 15:60-71

Levac E (2003) Palynological records from Bay of Islands, Newfoundland: direct correlation of Holocene palaeoceanographic and climatic changes. Palynology 27:135-154

Levac E, Sandercombe S, Chmura GL (2018) The Younger Dryas in palynological records from the northern Northwest Atlantic: does the terrestrial record lag the marine and air records? Palaeogeogr Palaeoclimatol Palaeoecol 490:269-279

Liebmann MJ, Farella J, Roos CI, Stack A, Martini S, Swetnam TW (2016) Native American depopulation, reforestation, and fire regimes in the Southwest United States, 1492-1900 CE. Proc Natl Acad Sci USA 113:E696-E704

Lindskoug HB, Marconetto MB (2019) Reconstruction of fire history using 'Dry' sediments, an approach for microcharcoal studies from the Sierras Pampeanas, NW Argentina. Environ Archaeol 24:61-78

Liverman DG (1994) Relative sea-level history and isostatic rebound in Newfoundland, Canada. Boreas 23:217-230

Long AJ, Barlow NLM, Gehrels WR et al (2014) Contrasting records of sea-level change in the eastern and western North Atlantic during the last 300 years. Earth Planet Sci Lett 388:110-122
Mannion JJ (1977) The Peopling of Newfoundland: Essays in Historical Geography. Social and Economic Papers No. 8. Institute of Social and Economic Research, Memorial University of Newfoundland, St. John's

Martijn CA (2003) Early Mikmaq presence in Southern Newfoundland: an ethnohistorical perspective, c. 1500-1763. Nfld Labrador Stud 19:44-102

Mauquoy D, Hughes PDM, van Geel B (2010) A protocol for plant macrofossil analysis of peat deposits. Mires Peat 7:1-5

McAndrews JH, Berti AA, Norris G (1973) Key to the quaternary pollen and spores of the great lakes region. Royal Ontario Museum Life Sciences Miscellaneous Publication, Royal Ontario Museum, Toronto

Medeanic S, Costa CS, Diniz D (2016) Modern pollen-vegetation relationships in saltmarsh habitats along a salinity gradient of a fluvial estuary. Rev Palaeobot Palynol 233:67-76

Moore PD, Webb JA, Collinson ME (1991) Pollen analysis, 2nd edn. Blackwell Scientific Publications, London

Mudie PJ, McCarthy FM (1994) Late Quaternary pollen transport processes, western North Atlantic: data from box models, crossmargin and NS transects. Mar Geol 118:79-105

Paquette N, Gajewski K (2013) Climatic change causes abrupt changes in forest composition, inferred from a high-resolution pollen record, southwestern Quebec, Canada. Quat Sci Rev 75:169-180

Pastore R (1989) The collapse of the Beothuk world. Acadiensis 19:52-71

Patterson WA III, Edwards KJ, Maguire DJ (1987) Microscopic charcoal as a fossil indicator of fire. Quat Sci Rev 6:3-23

Pendea IF, Chmura GL (2012) Calibration of pollen assemblages and carbon-nitrogen ratios to discriminate boreal wetland types. Rev Palaeobot Palynol 174:48-56

Pires EF, Medeanic S (2006) Palynological implications of the presence of "Triglochin" in Holocene palaeoenvironmental reconstructions in the coastal plain of Rio Grande do Sul State, Brazil. Rev Esp Micropaleontol 38:93-101

R Core Team (2019) R: A Language and Environment for Statistical Computing. R Foundation for Statistical Computing, Vienna, Austria. https://www.R-project.org. Accessed 24 June 2020

R Development Core Team (2010) R: A Language and Environment for Statistical Computing. R Foundation for Statistical Computing, Vienna, Austria. http://www.R-project.org. Accessed 30 June 2011

Raposa KB, Weber RL, Ekberg MC, Ferguson W (2017) Vegetation dynamics in Rhode Island salt marshes during a period of accelerating sea level rise and extreme sea level events. Estuar Coasts 40:640-650

Reimer PJ, Baillie MG, Bard E et al (2009) IntCal09 and Marine09 radiocarbon age calibration curves, $0-50,000$ years cal BP. Radiocarbon 51:1,111-1,150

Roberts BA, Robertson A (1986) Salt marshes of Atlantic Canada: their ecology and distribution. Can J Bot 64:455-467

Roe HM, van de Plassche O (2005) Modern pollen distribution in a Connecticut saltmarsh: implications for studies of sea-level change. Quat Sci Rev 24:2,030-2,049

Schmidt MWI, Noack AG (2000) Black carbon in soils and sediments: analysis, distribution, implications, and current challenges. Glob Biogeochem Cycles 14:777-793

Shaw T, Horton B, Kemp A et al (2017) Climate-related relative sealevel changes from Chesapeake Bay, US Atlantic coast. EGU Gen Assembly Conf Abstr 19:11,209

Simpson DN (1986) Prehistoric archaeology of the Port au Port Peninsula, western Newfoundland. Masters thesis, Memorial University of Newfoundland, St. John's 
Strachan KL, Hill TR, Finch JM, Barnett RL (2015) Vertical zonation of foraminifera assemblages in Galpins salt marsh, South Africa. J Foraminifer Res 45:29-41

Stuiver M, Reimer PJ (1993) Extended 14C database and revised CALIB radiocarbon calibration program. Radiocarbon 35:215-230

Stuiver M, Reimer PJ, Reimer RW (2005) CALIB 5.0. WWW program and documentation

Thannheiser D (1981) Die Küstenvegetation Ostkanadas (La végétation littorale de l'Est canadien). Münstersche geographische Arbeiten 10. F. Schöningh, Paderborn

Tolonen M (1983) Pollen evidence of vegetational change following early European settlement of Monhegan Island, Maine, northeastern USA. Boreas 12:201-215

Tourism, arts, culture and recreation (ND) archaeology sites in Newfoundland and Labrador. https://www.gov.nl.ca/tcar/archaeology-sites/. Accessed 19 Mar 2021

Troels-Smith J (1955) Characterization of unconsolidated sediment. Danmarks Geologiske Undersøgelse, 4. Række, Bd 3, Nr. 10:38-73

Wang J, Seliskar DM, Gallagher JL (2004) Plant regeneration via somatic embryogenesis in the brackish wetland monocot Scirpus robustus. Aquat Bot 79:163-174

Westley K, Bell T, Renouf MAP, Tarasov L (2011) Impact assessment of current and future sea-level change on coastal archaeological resources - illustrated examples from northern Newfoundland. J Island Coast Archaeol 6:351-374

Williams CG (2010) Long-distance pine pollen still germinates after meso-scale dispersal. Am J Bot 97:846-855

Wohlfarth B, Skog G, Possnert G, Holmquist B (1998) Pitfalls in the AMS radiocarbon-dating of terrestrial macrofossils. J Quat Sci 13:137-145

Wright A, van de Plassche O (2001) Field guide to the Quaternary west coast of Newfoundland. Geological Association of Canada-Mineralogical Association of Canada

Wright AJ, Edwards RJ, van de Plassche O (2011) Reassessing transferfunction performance in sea-level reconstruction based on benthic salt-marsh foraminifera from the Atlantic coast of NE North America. Mar Micropalaeontol 81:43-62

Wright AJ, Edwards RJ, van de Plaasche O et al (2017) Reconstructing the accumulation history of a saltmarsh sediment core: which age-depth model is best? Quat Geochronol 39:35-67

Publisher's Note Springer Nature remains neutral with regard to jurisdictional claims in published maps and institutional affiliations. 